\title{
SIDE LINE
}

\section{POULTRY KEEPING}

BY EDGAR WARREN

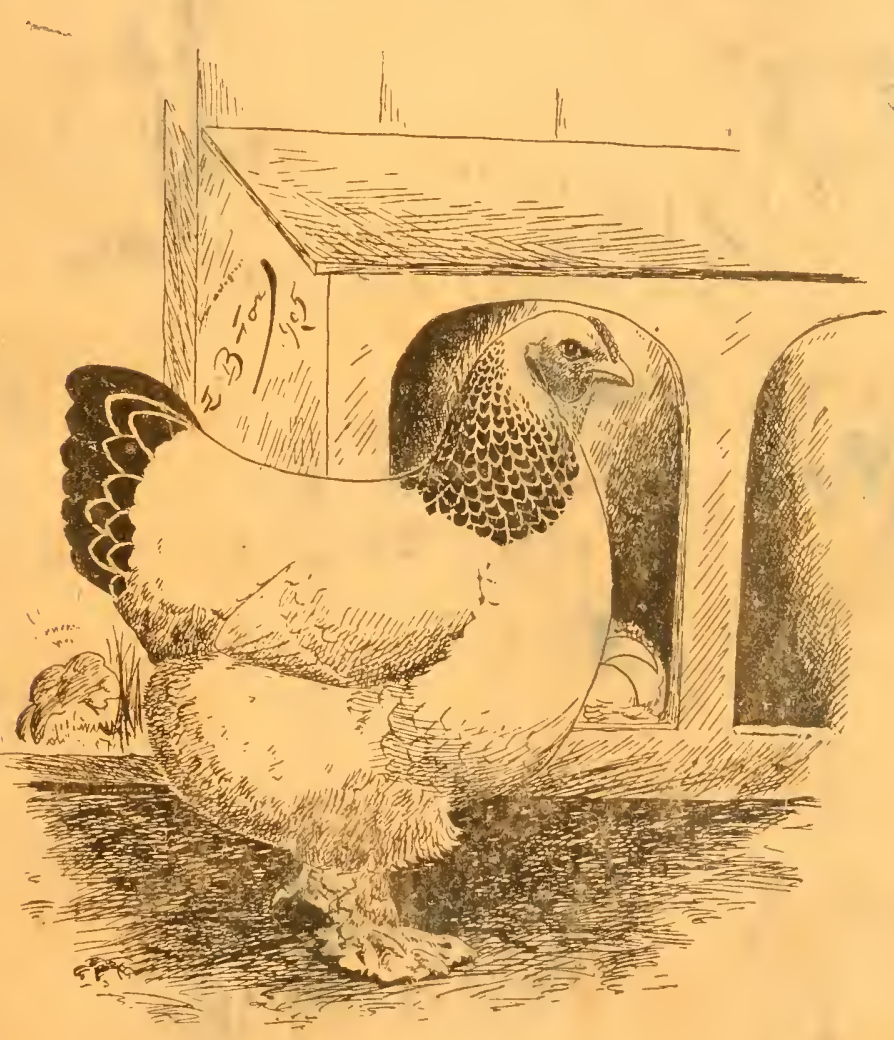

PRICE FIFTY CENTS

\section{PUBLISHED BY}

CLARENCE C. DE PUY. Syracuse, N. Y. 


$$
\text { ช }
$$








\section{SIDE LINE \\ POULTRY KEEPING

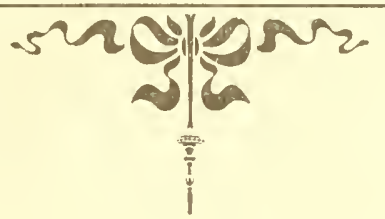

"IWO DOLLARS A DAY FROM POLTTRY AND EGGS" RETISED AND IMPROVEID. . . .

BY FDGAR WARREA.

PRICE JO C'ENTS.

Published by

CLARENCE C. DETUY.

Syracuse, N. Y.

1911. 
Copyrighted as "Two Dollars a Day Irom Poultry and Eggs," 1902. EDGAR L. WARREN.

(Edgar Warren.)

Copyrighted as "Two Dollars a Day trom Poultry and Eugs," 1909, EDGAR WARREN.

Copyrighted as "Side Line Poultry Keeping," 1911. EDGAR IVARREN. 


\section{CHAPTER I.}

\section{Side-Line Poultry Keeping.}

T'his book is rewritten to meet the needs of those who wish to keep ponltry as a side line. So far as the author knows it occupies a field peculiarly its own. Many books have been written about poultry keeping the past few years, and many articles have appeared in the papers on the subject, but the books and articles have been written either to give the general principles underlying poultry culture, to exploit some "system" or to describe some mammoth plant in which the writer or advertiser is interested. The man who wishes to keep hens as a side line, to add a few hundred dollars a year to his income or to reduce family expenses has been neglected.

Side line punltry keeping is destined to assume vast prominence in the future. There are two great movements in progress in the industrial world: the first is the movement to shorten the hours of labor; the second is the tendency of everything we buy to increase in price. The mechanic receives good wages and works short hours, but he can hardly support his family, to say mothing of laying up something for a rainy day. If he is to get ahearl, if he is to have a bank account, if he is erer to ovn a home, he mulst have some side line to occupy his spare hours and add to his monthly income.

The side line poultry keeper has certain great advantages. He does not take the chances the man takes who gives up his regular work to engage in the poultry business. His trade or occupation will give him a living while he is learning. He can begin small and grow. Then he has a market. The side-line poultry keeper is generally located in a city or large country village, and has customers at his doors. He takes every profit. He gets the whole of the consumer's dollar. Not so the man who is back on the farm. He sells to the grocer, who in turn sells to the commission merchant, who sells to the retail dealer. Who sells to the consumer. At least three profits are sacrificed. 'The side liner ean make his hens pay him at least a dollar more a head a year than can the man back on the farm. 
According to the census of 1910 there were 91,972,266 people in the continental United States, and of these 42,623,383 lived in urban and 49,348,883 in rural territory. Town-folk made up 46.3 per cent and country folk 53.7 per cent of our people. In 1900 the two elements stood at 40.5 and 59.5 per cent, respectively. Seven-tenths of our total gain in the decade from 1900 to 1910 went to urban territory; in other words, consumers are increasing more than twice as fast as producers.

Such being the case, the city must produce some of its own food or go hungry. Within the five-cent carfare zone of many of our cities there are houses with land that can be rented for less than a man would have to pay for far less desirable quarters in the congested district. What a blessing it would be to many a clerk or mechanic to move back a few miles from City Hall and rent one of these places! With his garden and small fruits and a good flock of hens he could easily pay his rent and lay up something besides. The productive years in a man's life are few at best, and unless he makes the most of them he faces an old age of penury and want.

A CASE IN POINT-MR. F. H. DUNLAP OF WEST SALISBURI. N. H., CLEARED \$1,188.05 FRUM POULTRY AND EGGS IN 1910.

Up anong the hills of New Hampshire, in the little town of Salisbury, one hundred miles from the metropolis of New England, lives a man whom I greatly adnire and respect. Big hearted, broad minded, breezy and optimistic, he is a good type of the men who are making this country great. Conducting the village store and postoffice, with not more than two hours a day on an average to devote to outside affairs, he has developed a poultry business which netted him $\$ 1,188.05$ profit in 1910 .

There were three sons in his father's family, and it was quite a question which one should stay at home to look after the old folks and carry on the father's business. The lot finally fell to Frank. He took his place behind the counter, married and settled down, and became a permanent fixture in the little village where he was born and passed his boyhood days.

The young man was soon confronted by a serious problem, and that was how to get ahead in the world. The profits 
of the store were just about enough to support his family, but not enougls to enable him to lay by anything. So he began to set his mind to work to devise means by which he might add to his income.

The story of the way in which he was led to take up poultry keeping as a side line is most interesting and amusing. One morning after he returned home from the city where he had been employed he was making a tour of the premises and for some reason or other went down into the barn basement. As he opened the door he was set upon by about twenty gaunt and eager hens, which, as he expressed it, seemed hungry enough to eat him up. Returning to the house, he asked his mother who fed the hens. She said, "I don't know; your father. I suppose." Hunting up his father, he put to him the same question. "Fred does, I guess," said his father. Hunting up his brother, he asked. "Fred have you fed the hens?" "Well, no, not to-day; I fed them yesterday, or day before. I forget which." "That settles it," said Frank. "I will feed them myself." So he got some grain, gave the hens a breakfast, rinsed out the water dish and gave then fresh. clean water to drink, and in this way "adopted" the homeflock of poultry as his part of the family chores. He kept an account of the grain, meal, etc., which he used in feediing them. fed them what he felt was a goorl ration, and in two weeks' time those hens, which before had been laying scarcely an egg a day, were turning out a dozen eggs a day, and at the price his father allowed him for them at the store he could see better than a hundred per cent profit in those dozen eggs a day.

\section{THE POULTRY PLAN'T}

Mr. Dunlap's plant, as it exists to-day, is an expansion from that snall begininng. It is not a large plant, two and one-half acres of sandy land shaped like a capital L. On what might be called the base or foot of the $L$ are the dwelling house and stable, a small lawn and garden, and the laying houses. On the shaft or stem of the $I$ are eight chicken houses, each $8 \times 12$ feet, situated one ahead of the other until the whole shaft is filled. I visited the plant in November, 1902, and again in August, 1911, and found that the plant had not grown in the meantine. There are two reasons for this: 1. The difficulty in getting more land; for, strange to say, in the country it is often impossible to induce the owner of a 
piece of land to sell. 2. The fact that the plant as it exists now is about all Mr. Dunlap can handle in the limited time at his command.

The poultry houses are good, substantial buildings, but not costly or elaborate. 'The eight chicken houses are each $8 \times 12$ feet, eight feet high in front and five feet at the back, with a lean-to shed roof. They are built of hemlock boards, covered with roofing fabric or half-inch hemlock sheathing; the roofs are shingled. All these houses have board floors, eighteen inches from the ground, and the chicks run under these houses in the summer.

There are five laying houses on the plant, three $30 \times 12$, one $60 \times 12$, and one $44 \times 14$. These houses are divided into pens ten feet wide, and in the winter accommodate about 500 head of laying stock. Two of these laying houses are twostory affairs, the upper stories being utilized for setting hens in spring. The houses have cement floors. They are not model houses in any way, but just plain, serviceable houses such as have grown out of the builder's needs.

\section{THE LAYING STOCK.}

Mr. Dunlap aims to winter five hundred head of laying stock-four hundred pullets and one hundred year-old hens. These are kept in flocks of twenty-five each. The majority of the birds are Rhode Island Reds, although there are a few White Leghorns. There are also crosses of the two breeds.

\section{METHOD OF FEEDING.}

Mr. Dunlap has developed a method of feeding, highly original and exceedingly effective. Where one wants a large egg output and is willing to put in a little extra time for the sake of getting it, no better method could be adopted. It is an economical method in all but time, the feed-bills being cnly about two-thirds what they would be under a different system.

Mr. Dunlap sticks to the wet mash. Every morning in the year his hens are fed a warm mash, mixed up the night before and so compounded that when fed it is moist and crumbly, but not sloppy. In the chapter on "The Laying Stock" I say that one of the fundamental things in feeding hens is to give them variety. Mr. Dunlap believes in this. He has four combinations, which he feeds on consecutive days, and which 1 will describe, designating each day by the leading ingredient in the combination. 
Boiled Potato Day.- Proiled putatues, one peck; gluten. four quarts. The potatoes are boiled the night before; the gluten is added after the potatnes are boiled; the mass is allowed to stand on the stove over night.

In the morning add two quarts bran, two quarts "provender" (cracked corn and oats), three pints of beef scrap or animal meal.

Steamed Clover Day.-Take a peck of second-crop clorer hay, chopped fine, pour on boiling water and let it stand in a covered kettle over night. Tn the morning add bran, provender and beef scraps as on "Boiled I'otato Day."

Waste Bread Day.-Mr. Iunlap buys waste bread by the barrel, having it shipped up from Boston. This is soakerl over night in boiling water, and in the morning bran, provender and beef scraps are added as before.

Oats and Gluten Day._- Soak eight quarts of oats in boiling water; pour off some of the water and add two quarts gluten; mix them well together and let stand in covered kettle over night. In the morning add the same combination as on other days.

Salt is added to all these combinations in limited amount. except when waste brear is fed. This contains a small amount of salt which was put in before it was baked.

In giving the formulas I have been careful about preparation rather than to give the exact amount to feed to a given number of hens. The reader will have to learn how much his hens need by experience; they will need more on some days than un others. Feed all the mash they will eat up clean in from fifteen to twenty minutes. Never leave any uneaten mash in the dishes to sour.

In the moulting season Mr. Dunlap frequently adds a quart of linseed meal to the combination, to promote the growth of feathers.

Besides the morning mash Mr. Dunlap keeps a hopper of dry feed in each pen all the time, so that the hiddies can help themselves. The combination is as follows: Two quarts alfalfa; two quarts bran; two quarts "provender" (cracked corn and oats); one quart chopped clover; one quart middlings; one and one-half quarts beef scraps or boiled beef and bone; a little salt; a little charcoal.

If the hens are laying heavily and growing light, arld two 'fuarts corn meal to the dry feed. 
'The greater part of the day Mr. Dunlap is employed at his store, which is about a hundred yards from his place, so that it is necessary for him to economize in time in every way. As a matter of fact he does not have more than two hours a day on the average to devote to his fowls; if he gets more he has to take it out of the night. There are certain seasons of the year when he has to work by lantern light long after everyone else in the little village has gone to sleep. He has an hour at moon in which to eat his dinner, feed and water the hens, collect the eggs and do any little chore about the houses that must be done. In this noon hour Mr. Dunlap gives his hens their grain for the day. He selects the grain that he thinks will balance the ration fed in the morning and throws down enough to keep the hens scratching in the deep litter a good part of the afternoon. Boiled Potato Day he feeds oats, wheat, cracked corn or barley, sometimes separately, sometimes in combination. Steamed Clover Day he feeds cracked corn; Waste Bread Day, wheat; Oats and Gluten Day, barley or buckwheat.

Every fall Mr. Dunlap swaps one hundred bushels of hen manure for one hundred bushels of turnips, and this gives him his yearty supply of green food without any money cost. These turnips are cut through the middle, the two halves thrown on the floor of the pen, where the hens find them and idevour them greedily.

Upon referring to the figures which Mr. Dunlap gives us for 1910 it will be seen that he paid out for feed during the year $\$ 86.45$. This is exceedingly small, when you reflect that he sometimes has five hundred head of laying stock and a thotwand chicks on hand. Mr. Dunlap keeps down his feed hills in several ways. He buys in ton lots, and gets the discount. Ile mixes up everything himself, and does not pay a poultry sales house to do it for him. He utilizes waste material as far as possible and turns his Yankee shrewdness in trade to gowd account. Thus his green feed does not cost him a penny : the clover hay he cuts himself; the boiled potatoes are small mmarketable potatoes which can be bought for a few cents a bushel. In other words, he makes everything tell.

\section{REARING THE CHICKS.}

Limitations of space forbid me to enter into detail about this part of Mr. Dunlap's work. Like everything he does, his 
method of rearing the chicks is original and instructive. He hatches under hens and broods in brooders. In my mention of his laying stock I said that he aimed to winter five hundred head-four hundred pullets and one hundred yearling hens. The eggs fur hatching come from the year-old hens-Mr. Dunlap believes that one gets stronger chicks in this way. l'ullets are employed for sitters. "The meanest part of my work," says Mr. Dunlap, "is taking the chicks away from the mothers. I feel ashamed to look a hen in the face." He believes that it does a hen good to hatch a brood of chicks; she will lay all the better for the rest and change. Two 1)rooders are installed in each of the eight small houses I have described, and each brooder is filled with chicks. "I aim to put fifty in a batch," says Mr. Dunlap, "but often I am obliged to put in from sixty to eighty." The chicks are fed on chick feed at first, but after a few weeks are fed much the same as the hens. The yards where they are confined are as bare of grass as a bald-headed man's pate is of hair. Mr. Dunlap is obliged to cut grass and throw it into the yards for green feed.

"Are you ever troubled with white diarrhoea?"

"Sometimes-I don't know any poultryman that isn't."

"What do you do for it?"

"I use ammoniated citrate of iron, which I luy at the drug store. I put a quarter of a teaspoonful in a quart of waterenough to turn the water quite red-and let them take their wwn medicine. I keep this up a week or ten days, making the solution weaker as the chicks get over their trouble."

\section{MARKE'TING THE PRODUC'T.}

On account of his location, so remote from a big city. Mr. Dunlap is at a great disadrantage in marketing his product. He ships to Boston, selling to commission merchants there. He ships in +9-dozen egg cases and ships every day. The stage takes the case from his store to North Boscowan, and the express takes it there. It costs him 20 cents a case to get the eggs to Boston, and there is the commission to be deducted besides. Mr. Dunlap does not get fancy prices for his eggs. Fifty cents in winter is the top price, and they go as low as eighteen cents in the spring. "If I were near a good market," he says, "I could make at least one-third more every year than I do."

Besides his remoteness from market Mr. Dunlap has to 
contend with the rigorous winters of Central New Hampshire. "I have seen the humses so corered with snow that l could barely discern their outlines. In one big storm all I could see was the roofis. It took me from 7 oclock in the morning until 1 oclock in the afternoon to shovel paths and get the hens fed. 'Confound the poultry business! it's too strenuous for me, I thought. But that day I took ten dollars and seventy-five cents' worth of eggs out of the houses, and the feed cost just an even two dollars."

"When I was here before, in 1902, you sold your fowls alive. Do you do so now?"

"No; I have a better way. I pay a man eight cents a head to come to the house and get the fowls, take them home, kill and dress them, ship them to Boston and sell them to commission merchants there. All I have to do is to furnish the fowls and take the check."

"You think it better to kill and dress than to ship alive?"

"I do. There is quite a shrinkage in weight on live fowls. Then the commission men will write you that they found one or two dead in each crate. It's a lie; but you can't prove it. I get five cents a pound more on an average on each fowl, and the express rate is less. The gain is about twenty-five cents a bird."

\section{$\$ 1,188.05$ PROFIT IN 1910.}

Mr. Dunlap very kindly drew up for me a balance sheet of his business for 1910. The figures are so inspiring and instructire that I reproduce them here:

Poultry in account with

\section{F. H. Dunlap. \\ Debtor.}

Jan. 1 To 570 birds on hand (a $75 \mathrm{c} \ldots \ldots \ldots \ldots \$+27.50$

Oct. 1 To cash paid for breeding stock........ 23.00

Dec. 31 To casl paid for feed for year......... 867. 45

$\$ 1,317.95$

Creditor.

Dec. 31 By 625 birds on hand a $55 \mathrm{c} \ldots . . . \ldots \ldots$. \$ 468.75

Dec. 31 Py 0,5,020 eggs laid during year....... 1,621.91

Dec. 31 Ry poultry sold during year......... $415.3+$

Profit for year.................... \$1.188.05 
Profit per week................ \$22.85

l'rofit per day.................... \$3.25

No account is made for fowls consumed on the lome table.

THE BALANCE SIEE'T OF THE YEARS.

Mr. Dunlap began his experiment with hens in 1886, and began in a very small way. It took him six or eight years to get his plant to its present size, and he has not attempted to increase it. Iiut each year he makes it pay a little more. He took up poultry keeping as a means of getting something ahead. And in this he has been eminently successinl. The profits for the twenty-five years have been $\$ 13,400.41$. In other words, he is $\$ 13.400 .41$ better off than he would have been if he had not made the experiment. Out of the profits of his flock he has bought his land, erected his poultry buildings. built a fine house and stable, installed a water system, bought a horse, wagon, sleigh and harness, made necessary repairs; and should have a surplus of $\$ 7,255.41$ wisely invested, as no doubt he has. Besides the financial returns poultry keeping has given him a new interest in life, has made him many pleasant acquaintances and friends, and has given him quite a renown. It certainly has paid.

MR. R. A. RICHARDSON, A SHOE CUTTER IN HAVERHILL, MASS., IAID BY \$1,009.31 I 1910

FROM HIS HENS.

I could go on and cite instance after instance where ment are making good money on the side with their hens, but I have not space to do so. Nor is it necessary. Two or three examples are as good as a thousand. Mr. Dunlap is an illustration of what a man way back in the country can do. I am now going to show the possibilities of a city lot.

Mr. R. A. Richardson is a shoe cutter in Haverhill, Mass., a city of about forty thousand inhabitants, situated on the banks of the rolling Merrimac. He has been interested in poultry for many years and when he was younger bred show specimens.

Iwelve years ago Mr. Kichardson legan to think seriously about the future. He was married and had a little family, and had nothing to support them but his earnings at the shoe bench. Shoe manufacturing is a peculiar business. Twice a year the shops shut down for several weeks. or run with a reduced force, and although a shoe cutter makes good wages 
when he works, there is much lost time. Suppose sickness should come, or accident, what would happen? What would become of him and his family when he was too old to work? for in shoe factories young men are given the preference. Mr. Richardson saw but one chance for himself, and that was to take up a sicle line. But what should it be? He had no capital and no credit; literally, not a dollar in the world.

His thoughts turned to the poultry business, with which he had some acquaintance. He could start in that with very little capital. Mr. Richardson had visited the shows and he knew that many people were interested in fancy poultry. He had read of the prices paid for exhibition stock. He reasoned out that for him there was a better field in utility than in exhibition stock; for ten persons are interested in utility stock to one who is interested in show specimens.

Mr. Richardson started out with the ambition to produce the greatest strain of layers in the world, and settled upon the White Wyandotte as the bird best adapted to his purpose. The White TYyandotte lays a brown egg, and a brown egg is called for in the Boston market. The White Wyandotte has a large breast development, which makes it an ideal bird for a broiler. It is larger than the Leghorn and makes better poultry. It seened to combine all the good qualities more than any other breed.

Mr. Richardson reasoned out that the only way to get great layers was to breed from great layers, and he installed trap nests and kept the record of every hen. This he could not possibly have done without the assistance of his wife. "She is as interested in the business as I am," said Mr. Richardson to the writer. While he stood at the bench day after day cutting out soles and uppers, his wife was busy with the birds, and every time a hen laid an egg she was given credit for it in a book. As a result of this careful, conscientious work carried on for twelve consecutive years Mr. Richardson has developed a strain of phenomenal layers.

When his strain was sufficiently established to justify it. Mr. Richardson began to advertise in the poultry papers. He now has calls for stock from all over the United States and Canada, and from across the water. He does not get the prices fanciers get for their birds, but still receives a satisfactory remuneration. The highest price he ever received was $\$ 45$ for a cockerel and hen; but $\$ 25$ for a cockerel and $\$ 10$ to $\$ 15$ for a pullet are not uncommon figures. Of course he 
has many birds that he sells for much less. From the sale of breeding stock and eggs for hatching combined with market eggs and fowls sold for eating, Mr. Richardson cleaned up $\$ 1,009.31$ in 1910, and kept his job as a shoe cutter besides!

Mr. Richardson has an acre of land on Linwood street in Haverhill, about a mile and a half from the center of the city. The ground is high, and the view from the plant is delightful. The buildings are not imposing. There is a long laying house $60 \times 12$ feet, divided into six pens, with dirt floors. This house is cheaply constructed and is covered with a red roofing paper. He has a chicken house $25 \times 8$, divided into three pens, and a brooder bouse $6 \times 6$. "Put your money in stock rather than in buildings," is Mr. Richardson's advice, and he practices what he preaches. "Start with the best stock you can get hold of. I'ay $\$ 25$ for a single bird, if necessary. Don't hesitate a minute, if it is worth it. The more money you pay for stock, other things being equal, the more money your stock will earn for you."

Mr. Richardson's poultry business is growing so fast that he is seriously contemplating giving up his job in the shoe shop and deroting all his time to it. $\mathrm{He}$ is negotiating for two acres of land which joins his, and if he gets it will greatly enlarge his plant. He now carries from 150 to 175 breeding birds through the winter and raises about 300 chicks.

Twelve years ago Mr. Richardson did not have a cent. He now owns a house and lot, has a good equipment and has money in the bank-all the result of side-line poultry keeping. And he is a comparatively young man yet! 


\section{CHAPTER II.}

\section{Making a Start.}

The great advantage of side-line poultry keeping is that a man can make a start and get his experience while working at his regular business. I hope the reader of this book will dismiss from his mind at once any thought that poultry keeping is a get-rich-quick scheme. It is not. There is good money in the business, as I have shown and shall show, but not every one can get hold of it. Doubtless the proportion of failures is as great in the poultry business as in any other. Riding through the country one sees plant after plant abandoned and falling into decay. One is continually meeting the man who was once enthusiastic orer poultry keeping, but is now disillusioned and tells you sadly, "There's nothing in it." And when a man buys a poultry farm his neighbors shake their heads and prophesy failure.

\section{EXPERIENCE NECESSARY.}

The causes of failure in the poultry business are doubtless as numerous as in any other, but the cause that is the most prolific is inexperience. There are three things that every man seems to think he can do: preach the Gospel,: edit a newspaper, and run a poultry plant. But he finds if he tackles any one of these jobs that he is up against a bigger proposition than he realized.

Some time ago I received a letter from a woman whose husband had made some money in the drug business and now wanted to get away from it into the freer life of the farm. There was a poultry plant near where they lived that was for sale, the owner having made a failure of it, and the woman wrote me to know what chance her husband would have for success if he sold his store and bought the plant, knowing nothing of the business. I wrote back that he would have just exactly the same chance that a man would have who knew nothing of the drug business and who should buy out her husband's store. Set it down as the basic principle in all your calculations, that the poultry business requires just as careful 
an apprenticeship as any other, and that the man who is to succeed must know it root and branch.

\section{BEGIN SMALL AND GROW.}

Fortunately a man can serve his apprenticeship to the poultry business while he is earning his bread and butter at something else, and this to me is one of its chief charms. In what wher business in the world can a man begin so small and invest so fittle money at the start? If a man has an old dry gonds box at his command, a sitting hen and a clutch of eggs, he can set his feet in a path that may lead on to fortune.

Sars "Commercial Toultry": "It is a matter of history that nearly every une of the large poultry plants in the United States that has proved successful has been huilt up from a small fumndation. It is also a matter of history that there are a number of large plants that have proved unsuccessful and unprofitable simply because the owner undertook to accomplish sontething without fitting himself for the task. Those who have succeeded have been content to start in a small way and expand as their linowledge of the business and their abiilty to handle it warranted the expansion.

"Take, for instance, the plant of U. R. Fishel at IIope, Ind., White I, eghorn Poultry Farm at Waterville, X. Y., H. I. Blanchard at Groton, X. Y.. Henry Tan Dreser at Cobleskill, N. Y.. and many other of the largest and most profitable plants in the country-each of them had a mall beginning and simply grew into the manmoth institutions that they are to-dar.

" $\mathrm{C}$. R. Fishel started with a few hens in a back yard a dozen years ago. To-day he has 120 acres devoted to poultry and does an annual husiness very close to the $\$ 20,000$ mark. The White Leghorn Poultry Farm at Waterville, N. Y., is the ontgrowth of a score of hens kept in a house less than eight feet square the first winter. Th-day the farm consists of about 160 acres- with a recent addition-with a score or more of large houses, the largest being 500 feet long. N1though ten thousand S. C. White Leghorns are raised annually upon this farm, the demand for stock and eggs nearly always exceeds the supply. H. J. Blancluard of Croton, X. Y., has become wealthy from his chicken business, although he has a farm of but twenty acres. Tlenry Van Dreser started in a small way and tr-day has one of the largest commercial and fancy poultry plants in the East." 
"The sane is true of almost every large poultry plant in the country. There are a few, to be sure, that have been started on an extensive scale by men of wealth, but if they have proved successful it is because experienced poultrymen have been employed to manage them."

\section{THE FIRST STEP.}

Suppose a man has no practical knowledge of the poultry business. but has become interested in it from reading about it in the papers and talling with friends, how would I advise him to proceed? It would depend something upon the season of the year. Suppose it to be fall. I would advise him to send away to a breeder of established reputation for a breeding pen of the variety he has selected. A breeding pen consists of a male and four females, and may generally be purchased for from $\$ 15$ to $\$ 25$. The breeding pen may consist of four pullets and a cock, but I think it better to rererse the arrangement and purchase four hens and a cockerel. Pullets are all right to breed from, provided they are mature; but these are the kind the breeder does not care to sell. On the other hand, he is always ready to dispose of his mature birds. From such a pen as this a man should get from 150 to 200 chicks in the spring, and have a good number of choice pullets and cockerels in the fall.

Four hens will not be enough to keep a vigoruns cockerel at work, and so I would advise the beginner to pick up eight mature, well-grown pullets around home. These may be put in the pen with the rest. But before this is done, they should be well dusted with some good insect powder, for farmers' hens are proverbially lousy and if not "doctored" will infect the rest.

These eight pullets of nondescript variety will do for sitters and mothers in the spring. The four hens should give you at least $6_{0}$ eggs apiece during the hatching season, and if the eggs are reasonably fertile you should get from 150 to 200 chicks. From these you should get a good number of pullets in the fall.

'The advantage of starting with a breeding pen is that one will be likely to have eggs on hand whenever they are wanted, and there are no delays, no eggs chilled or broken in transit. The male with which you started should be kept the second year and mated with pullets of his own get.

starting in the spring one would naturally begin with eggs. 
Ton will need at least 100 to give you anything of a start, and these will cost you $\$ 10$. Beware of cheap eggs and cheap stock. You will never be satisfied until you get goud standarrl b)ed fowts, and these cannot be produced or sold for the price you pay for dunghills. It has been my experience that the bircls I paid the most for at the start were the greatest moneymakers in the end.

\section{KEEP ONLY THOROUGHBREDS.}

It seems almost nmecessary at this stage of the world's histury to adrise the prospective poultryman to keep only thoroughbreds, and yet one still meets the man who insists that crosses or mongrels lay as well and pay better than they. Let us examine this proposition a moment. If mongrels and crosses lay as well and pay better than thoroughbreds. why is it that the great commercial plants throughout the land have discarded them in favor of standard-bred fowls? Why is it that the great egg records, as shown by the trap nest. uniformly come from thoroughbreds and not from mongrels or crosies? It costs no more to raise a thoroughbred than a donghill, no more to feed it after it is raised. A flock of birds of one variety looks better than a flock made up of everything under the sum, and will do better. J)ifferent breeds require different treatment, and where they are all mixed $u_{1}$ in one fock conditions cannot help being unfarorable to some. Eiggs coming from one breed are nore nniform, and when the birds are sent to market they bring two or three cents more a pound than a mixed lot. Where a man keeps only pure-bred fowls of some popular strain he can, even without advertining. sell a gond many sittings of eggs to his neighbors in the spring and dispose of his surplus cockerels to them in the fall. Time and time again have I had risitnrs come to my place, who had no intention of purchasing when they came, who became so fascinated at what they saw of my beautiful White Mrandottes that they placed a gomd order with me before they went away.

\section{RREETS TIIAT PAY.}

() ne of the difficulties of the beginner is to determine what rariety to keep. The latest edition of the Standard of T'erfection recognizes seventy-five or more varieties of the domestic fowl, not including Bantams, which are miniature or dwarf specimens of the rarious breeds. Should a man in this 
undecided state of mind risit a great show in which are exhibited the best specimens of all the leading varieties-the aristocrats of foultrydom-his confusion becomes worse confounded: and should he run across champions of several of the leading breeds and let them talk to him for half an hour each, his mind will be in such a whirl that it is impossible for him to make a decision. It is to help clear up the whole matter that this section is written.

The money-making varieties may be counted up on the fingers of both hands. I do not mean by this that men do not make money on other varieties, for they do; but there are six or eight varieties which pay well in the hands of almost anyone. If a man is to become a fancier or a specialist it nay be wise for him to $g o$ afield and take an entirely different breed: but if a man is after a safe, conservative proposition he would hetter stick to the varieties I am about to mention.

1. The Leghorns. Brown and White. The Leghorns have been denominated "egg machines." and they well deserve the appellation. They are prolific producers of white eggs; mature early, are active, hardy and do not eat so much as the larger hreeds. Non sitters. In some markets white eggs are demanded by the best trade, and command a preminm.

2. Rhode Island Reds. A valuable addition to the American class. Hardy, good layers of brown eggs, a rich yellow carcass, good table bird. Nature early.

3. The Wyandottes. White, Columbian and Buff. Perhaps the most popular breed in the country to-day. Prolific layers of brown eggs; yellow skin and legs. A prime table fowl. A favorite on broiler plants. "No matter when you kill them, you've always got something."

f. Plymouth Rocks. Barred and White. A close second to the Wyandottes in the race for popularity. A fancier's and a farmer's bird. The Barred Rock is known as the business hen. Ilardy, large sized, prolific layers of brown eggs: killed and dressed they make splendid poultry.

5. Black Minorcas. A handsome showy bird of the Mediterranean class. In size nearly equal to the Plymouth Rock. Heary layers of large white eggs. Fair poultry.

6. Black Langshans. A noble bird of the Asiatic class. I arge size, the cock weighing 10 pounds. Excellent table 
fowl, the meat having a delicious flavor, and the bones being small. Lay a beantiful brown egg.

7. The Orpingtons. Buff, Black and White. Large, stately birds; larger even than the Plymouth Rocks. Rightly handled they make excellent layers. Good table fowls. They would seen to have a great future.

\section{EXHIBITION POULTRY.}

Men who engage in poultry keeping as a side line are in a peculiarly favorable situation to take up the breeding of exhibition birds. As a general thing they have more money to spare for foundation stock and poultry appliances than the man who attempts to run a poultry farm. Then with their time and mind largely accupied with other things they turn to poultry keeping as a recreation, and do not become weary of the infinite details that make drudgery of the practical poultryman's day. Consequently they give their stock better care. There are many who, if they realized the money there is in breeding exhibition birds, would make an attempt to get some of it. There are rich men who are willing to pay almost fabulots stms for hirds that can win the blue ribbon at one of the large shows. And the market for such fowls is not confined to the limits of the United States, but is as wide as the world. George H. Northup of Raceville, N. Y., recently sold to Henry Schultz von Schultzenstein of Berlin, Prussia, two rose comb Black Minorca cocks for $\$ 500$ and $\$ 1000$ each respectively. The 19 birds which he sold to this gentleman brought him in $\$ 3400$. Mr. Northup gets \$25 a sitting for eggs from his best pens. William Barry Owen of Vineyard Haven, Mass, has in his circular a list of 30 fowls, the value of which is $\$ 10,000$. The leader of the list is a Black Orpington cock which won first New York, first Boston, 1906, first world's trophy. Crystal l'alace. London. 1905, and is valued at $\$ 750$.

The record, however, was reached in March, 1908, when Madame Helena Paderewski of Morges, Switzerland, wife of the world-famous pianist, paid to Ernest Kellerstrass of Kansas City, Missouri, $\$ 7500$ for five crystal strain White Orpingtons, the highest price ever paid for standard-bred birds since the world began. Mr. Kellerstrass refused $\$ 2500$ for one hen, "Peggy," as it was named after his little girl, and, being a rich man, he did not need the money.

These of course are top-notch prices, and are paid only for 
world-beaters, but $\$ 100$ for a single bird and $\$ 10$ a sitting for eggs are everyday occurrences. Even at one of the smaller shows a winner in one of the popular classes will bring from $\$ 25$ to $\$ 50$. The beaty of this branch of the business is that it does not require a large amount of land nor a large outlay for buildings, and a man who has skill in mating may grow a blue-ribbon winner in his back yard.

\section{THE PHILO STSTEM.}

There are, as everybody knows, two systems of keeping fowls- the intensive and the extensive. The intensive makes the individual the unit and seeks to secure the largest profit possible from each hen; the extensive makes the flock the unit and seeks to secure the profit from the aggregate of fowls rather than from the individual. The Philo System is the intensive srstem carried to a point that many would consider extreme. Six females and one male constitute a unit or flock. These little flocks are kept in houses which Mr. Philo describes in his book, each flock having a house of its own. There are two styles of these houses or coops, the standard and the economy. The standard coop is six feet long by three feet wide, and four feet high to the eaves. Above the eaves there is what Mr. Philo calls a "gable"-a double-pitched roof, one side of which can be raised at will. This "gable" makes the extreme height of the house five feet. The standard coop has two stories - the roosts, nest boxes, feeding troughs, etc., leing in the upper story. The "economy" coop is six feet long, three feet wide and two feet high. It has an adjustahle cover that can he raised or lowered at will, and fastened at an angle that will keep the rain or snow from entering the coop. It also has a sliding muslin frame which can be moved to the right or left, so that the fowls may be cared for without daily adjusting the roof in hot weather.

After the fowls are installed in these coops they are not supposed to go outside. In the narrow limits at their command they live and move and have their being. And singtlarly enough, they do well. They seem happy and contented and often respond with a large egg yield. Adrocates of the system say that hens get their exercise by scratching. not by roaming, and that a hen can get just as much exercise in a six by three coop as in a ten-acre lot.

Advantages. - What are the advantages of the system? Why are so many enthusiastic over it? Why has Mr. Philo's 
little book sold over a quarter of a million copies? The answer is very simple: The Philo system has made poultry keeping possible to thousands who otherwise could not engage in it.

There are thumands living in cities who would like to keep hens, lut who have hitherto been debarred of the privilege because they had no suitable place. But with the Philo system anyone who has a back yard and a few feet of space may keep a little flock and supply themselves with fresh eggs, if nothing nore. It costs little to make a start. Where one does his wrn work an "economy" coop may be knocked together in an evening at a cost of two dollars for materials, and the hens may be as low-priced as one wishes. If one gets tired of the venture the hens mav be sold or killed and the coop split up into firewood. In this case one has had a new and pleasant experience at littie cost.

Disadvantages.- And $110 \mathrm{w}$ what are the disadvantages of the system, the arguments against it? It requires a vast amount of work on the part of the poultry keeper. work that might be productive of far larger results. The time required to care for six hens and a cock under the Philo system would be as much as would be required to care for fifty hens in a larger louse. And this work has to be done in the open air. It is delightful on a pleasant summer morning to go around among the little coops and look after their occupants; but in winter, when the mercury is at zeru and a storm of sleet smites the face, it is not so fune. Ind even in the summer the system is not altogether a poem: lice multiply in the little coops with startling rapidity, and the poultryman has to be ever on the alert or his birds will be eaten $u p$.

And ret Mr. E. R. Philo has rendered a great service to the poultry fraternity: he has made it possible for thousands to engage in poultry keeping who without his book never would have made a start. 


\section{CHAPTER III.}

\section{Side Lines That Pay.}

While this book is written primarily from the standpoint of the poultry keeper, yet it is also written with the view of helping out that large class made up of those who have a little land who want to add a few hundred dollars a year to their income. Hens work in well with other things. They do not take all a man's time, not even all his spare time, unless he keeps enough to make a slave of himself.. In fact, it is often more profitable to combine hens with other things, even when but a small number are kept, than it is to depend upon the hens alone. They furnish a valuable fertilizer, which should be utilized; and this suggests a garden. They enrich the soil of the yards where they are confined and keep down the weeds; and this is favorable to the growth of berries and fruits. They consume by-products that would otherwise be wasted, and these by-products should be manufactured, if the feed bill is to be kept down.

\section{PIGEONS.}

Where a man is properly located there is no side line that will give him better returns than pigeon raising. I an aware that pigeon raising as a business enterprise is looked upon with suspicion by many,-such extravagant claims have been made for it by those who have stock to sell. And yet an acquaintance with the business has convinced me that where a man is well located with reference to markets, begins on a small scale and thoroughly masters the subject, gives his pigeons careful attention, there is no line in which there is such "easy money" as squab growing.

To begin with, pigeons are much less care than hens: they look after themselves. In pigeon raising the most laborious and unsatisfactory part of the hen business is eliminated: the incubation and care of the young. There is no incubator to manage, no "moisture problem" to trouble one, no fussy sitting hen to bother with, no brooder to look after. Pigeons build their own nests, hatch their own eggs, rear their own young, and take care of them until they are ready to be sent to 
market or start in to housekeeping for themselves. If mecessary, one can leave his pigeons all day, while he attends to other work, as there are no eggs to gather and the flock may be automatically fed.

A pair of good-working Ilomer pigeons will rear from six to eight broods of young ones in the course of a year, and 1 have known an unusually good pair to rear eleven broods. Squabs bring from to to 60 cents a pair in the Boston markets. according to the season. It is estimated that it costs 10 cents a month to feed a pair of Homers, and the old birds feed their

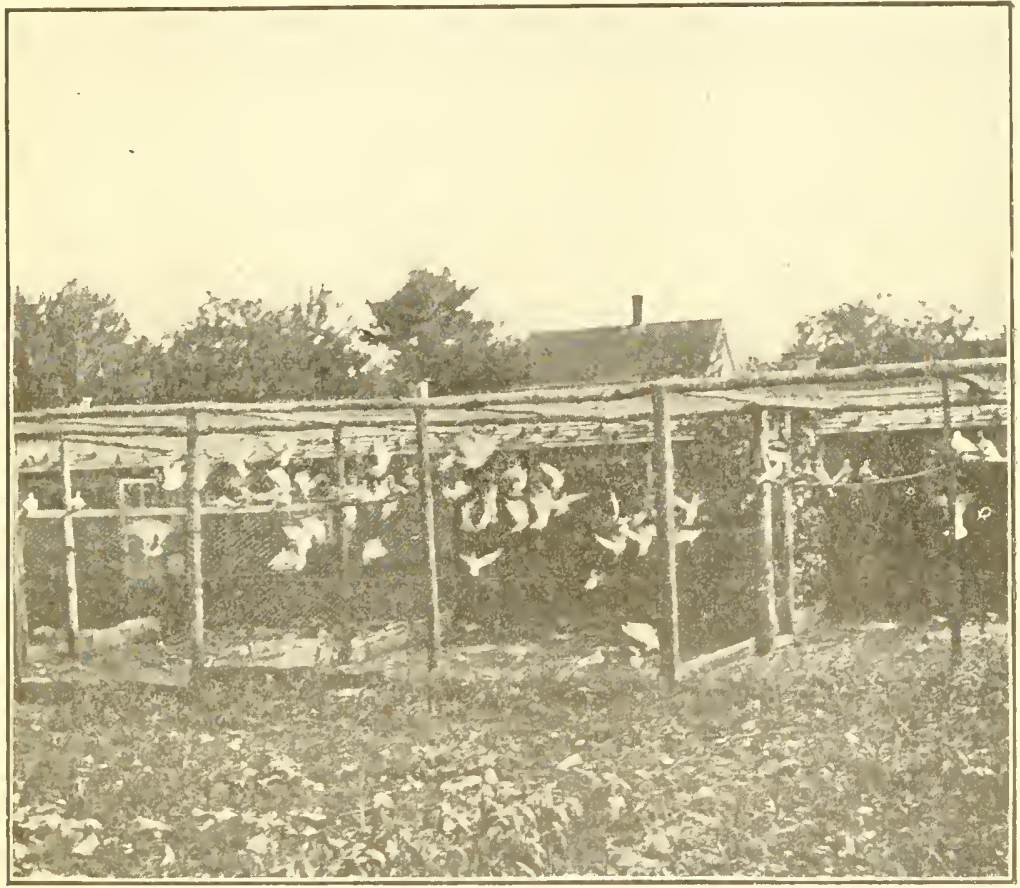

Scene in the Pigeon Yard on a July morning-The Building where 250 pigeons are housed cost but $\$ 50$. It was originally a hen house.

own young. Reckoning the price at which squabs may ho sold at the minimum, 40 cents a pair, and the increase eight lair a year, cost of feeding, $\$ 1.20$, and we have a net profit of two dollars from each pair of working Homers. I know a successful business man who draws $\$ 50$ a week from his business for personal expenses. This man engages in pigeon raising as a side line. And he tells me that the money comes easier from his pigeons than it does from his business. 
Any homse that is adapted to poultry is adapted to pigeons. It is generally safe to allow five square feet of floor space for each pair, and not put over 25 pairs together in a pen. Besides the house space, pigenns need a flying pen, which should be at least twice as large on the ground as the breeding pen. the flying pen should be eight or ten feet high, and should be roofed with poultry wire as well as have poultry wire on the sides.

The two secrets of successful pigenn raising are perfect sanitation and complete mating. P'igenns are subject to two serions diseases-canker and diarrhoea. Canker is a filth disease, and diarthea is cansed hy improper or unseasonable diet. If the water for the daily bath is allowed to stand long cnough to become polluted and the pigeons drink it, the germs of canker are introduced. And if care is not exercised in regard to dict. diarrhoea is likely to break out.

Pigeons are generally given their feed in hoppers, and the standard ration is a mixture of red wheat and cracked cornmuch more corn being fed in winter than in sumner. Pigeons are also given peas, kaffir corn and pigeon feed. Grit and charcoal must be kept before them all the time and also plenty of oyster shells. I'igenns build their own nests (two boxes being provided for each pair), but must be furnished with nesting material-tobaco stems in summer and straw in winter.

Sinabs are generally marketed when four weeks old. Their necks are wrung and they are shipped undressed. They are handled by commission merchants, who pay from 40 to 70 cents a fair for squabs weighing from 9 to 10 pounds a chenen. according to the season of the year. Prices are at their lowest in June and July and at their highest in February and March.

'lo realize the largest profits one needs a good summer market close at hand. In many places this market already exists, and in nearly every place of any size it may be created. The consumption of squabs is likely to largely increase in the future, and there does not seem to be any danger that the business will be overdone.

Pigem raisers may add considerably to their profits by selling birds for breeding purposes. Pigeon raising is a new business in most localities, and its picturesqueness and possible profitableness make a strong appeal to many. Scores start in with a few birds in every village every year, only to abandon the enterprise in a few weeks or months, and these 
beginners make good customers for stock. In pigeon raising, as in everything else, it is the man who stays with the business who succeeds.

\section{1) U'KS.}

The profitableness of duck culture is mot preached so assiduonsly as it was a few years ago, but where a man's place is adapted to it and where he is well located as regards markets, he may, as in the case of pigenns, embark in it to adrantage. Jucklings are easier to raise than chicks, grow faster, are unmolested hy rermin and are not subject to disease. They are easily confined-a two-foot wire fence will keep them enchsed. Thile a stream or pond is an advantage in raising ducks, yet sume successful duck raisers grow then without this accessory. They need plenty of water to drink and to rinse their faces in, but more than this is not needed. In the case of ducks, besides the eggs and meat, there is another source of revenue-the feathers.

\section{PUL'TRY KEEIING IND GENERAL FIRMINO.}

As a matter of fact, three-fouth of the eggs produced in the l'nited States are profuced on farms, where poultry keeping is a sicte line. Hens pay on the farm, there is no dombt of that, but it is a question whether it would pay a man to combine poultry keeping on a large scale with general farming. Ilens pay on the farm because they are allowed to shift for themselves and pick up a great part of their own living. Fifty hens may range at will and not be a nuisance, but fire hundred hens roming at large would be as destructive as a Kansas cyclone. If a man keeps five hundred hens he must howse then, yard them, feed them, and derote considerable time to their care. It is a puestion whether this time nay not be more profitably spent in regular farm work. ()ther things being equal, it does not pay a man to disturb a routine he has established and which is reasonably profitable to try a new thing.

\section{MARKET GARDENING.}

Where soil and site are favorable poultry keeping works in well with market gardening, Summer, which is the market gardener's busy season, is the time when the poultryman's duties are light. The poultryman has at his command a large amount of stimulating manure, which is just the thing for 
early crops. It is surprising, tom, what a demand there is for early vegetables, even in country towns. Marketmen will tell you that they cannot begin to supply the demand from the local growers, but have to send away for a great part of their stuff. If a man has a small greenhouse he can add largely to his profits, and even with two or three hot beds can force the season. Asparagus, early peas, string beans, green corn, cucumbers, radishes, lettuce, beets, etc., are money makers not to be despised. The beanty of market gardening is that there is no long wait - a man gets returns from his investment at once.

\section{STRAIVBERRIES.}

Probably the ideal combination, where conditions are favorable, is poultry keeping and strawberry growing. Strawberries are the one berry of which people cannot get enough. It is surprising how many boxes the market will absorb. In the little town in which I live I have known one dealer to sell 250 boxes a day. In order to grow strawberries to adrantage three things are needed: rich, moist land, clean culture, plenty of cheap help in the picking time. By a suitable selection of varicties the fruiting season may be extended to full four weeks. For New England the following varieties are recommended: Early-Fairfield, Senator Dunlap, Virginia: midseason-Sample, Glen Mary, Abington, Brandywine. Minuteman, Parson's Beauty ; late-Stevens' Late Champion; latestRear Guard.

For growing on light soil, Ninuteman and Haverland pollenized with Meade or Senator Dunlap; for medium to heary soil, Sample pollenized with either Brandywine, tbington, Parson's Beauty or Senator Dunlap; Gen Mary. The latter variety may be planted alone if lesired. Plant new varieties in a small way, or better still, allow the experiment stations to test them for you.

The grower of strawberies may add considerable to his income by the sale of plants. There are many in erery community who have their own strawberry bed. They are accustomed to send away for plants, hut will buy at home if they can get what they want. One cannot get as large prices for plants sold around home as he could if he advertised and got out a catalogue; but half a cent a plant for the common varieties and a cent a plant for the newer ones will pay a man well. The question arises in this connection. If I sell plants do I not create competitors who will cut into my herry business? It 
is the experience of strawberry growers that the sale of plants does not injure the berry trade. New varieties are coming out all the time. If a man has a reputation for growing good stuff his customers will stick to lim. The way to succeed is to do things a little better and a little different from the othes fellow, and then let the public know it.

\section{RASPBERRIES, BIACKBERRIES AND CURRANTS,}

The grower of strawberries will be likely to add "bush fruits," as they are called, to his collection. Raspberries and blackberries are not so satisfactory to handle as strawberries. as it is more difficult to keep them under control; but where a plantation is well established it is profitable. Raspberries especially pay well, as the demand is good and the price high. The raspberry grower has a clearer field for his wares than the strawberry grower, for owing to the soft and fleshy nature of the fruit it does not stand shipment well and the demand must be supplied from near home. Currants alsu have a limited sale, and owing to their extraordinary productiveness are profitable. In raspberries the money making varieties are the Kansas and Cuthbert; in blackberries, the Suyder; in currants. Red Cross, Wilder or Cherry.

\section{PEACHES AND PLUMS.}

These du nut yield su quick returns as regetables, berries and bush fruits; but when the orchard is established, the work is less and the profits large. The poultryman who plants peaches and plums in his garden has the great advantage of using his land for a double purpose. Peaches are profitable in the peach belt, but when one gets out of the region where they grow naturally, it does not pay to bother with them. Plums are hardier and are adapted to a wider range of territory.

Any land that will grow good corn will grow peaches and plums. Some set the trees in holes dug for the purpose, but I get better results by plowing the land and growing the trees the first year or two among hoed crops. In buying trees get them as near home as possible. They will be more likely to live, as they can be set immediately upon being dug up, and the price is less. One should not pay over 10 or 15 cents for trees suitable to set out.

This book is written for the latitude of southeastern New England, and all varieties mentioned in this chapter are the ones adapted for money-making here. Other parts of the 
country will perhaps require a different selection. I would advise the reader to write to the pomologist of his State experiment station for a list of trees and fruits best adapted to his lucality. For my section the best varieties are as follows: Peaches-Greensboro, Waddell, Carman. Champion (delicious late peach), Elberta, Crosby (the best yellow peach known): plums-Red June, Abundance, Satsuma (superb for (anning).

\section{PROOIER PROKE CHICKS.}

There is a fine field in every community for one or two young men or women to make good money hatching out chicks for their neighbors. 'They should be equipped so that they can supply eggs from their own flocks from two or three standard varieties, and also be ready to hatch eggs that may be furnished them. The price of day-old chicks is about 15 cents for the standard varieties, and at this price there is good money in it.

The fireless brooder is the greatest discovery in the poultry world in the last five years. The fireless brooder makes it possible to raise chicks without danger or expense. A man running fireless brooders can go to bed at night with the comforting assurance that his chicken house will not be likely to burn down hefore morning. The cost of these brooders is so slight that they can be hurned up at the end of the season and new ones installed the following year.

The great whjection to the fireless brooder is that for two or three dars one has to practically live with the chicks. After the chicks become "brooder broke" it is no more trouble to run a fireless brooder than one of the combustible kind. Now I am coming round to the point of this article: It would be a great advance and a great advantage to buyer and seller alike if chicks could be sold "brooder broke" rather than right out of the incubator. It would be a great advantage to the purchaser because it would materially reduce his labors. and it would be of great advantage to the seller because it would almost double his profits. Many a mán who pays 15 cents apiece for day-old chicks would pay 25 cents each for chicks that had been brooder broke. And where a young man or woman is making a business of getting out chicks, they might as well put in a little more time and take the added profit. 


\section{CHAPTER IV.}

\section{Houses and Yards.}

One of the greatest problems that confronts the poultryman is the location and construction of his plant. It is here that more men meet their Viaterlow than anywhere else. I have visited many of the leading breeders of the East, and before coming away have asked this question: "If you were starting anew would you build and locate your houses just as they are now?" And in nearly every case, I think, the answer has been, "No." The man has gone on and suggested modifications and improvements that I could see would be of great advantage.

It is my purpose in this chapter to describe two poultry houses-one for layers and one for young stuck-such as I have demonstrated in my own experience to be practical and ecomomical. Indeed, I do not see how either of them can be impsoved. If a man will think out his plant in advance and determine where he will build if his business grows, and then begin with one laying house and two of the smaller houses, he will make no mistake, but will be in a position to advance from year to year.

\section{IA INGGHOLSE.}

There seems to be a tendency on the part of poultrymen to-day to larger flocks. There was a time not so long ago when it was believed that twelve or fifteen birds were all that should be kept together where the maximum egg product was desired. It has been found, however, that fowls may be kept together in any number up to fifty with good results, provided they are given ample rom and their quarters are kept clean and sanitary. It womld seem to be gond judgment. therefore, to build a house sufficiently large to accommodate 50 laying hens, and to make this number the nnit in one's calculations. Fifty hens in one flock may be cared for as casily as 15. They require but one feed hopper, one drinking dish, wne box with grit and oyster shells, one dust bath, and may all be fed their grain ration at the same time. A 50-hen house, therefore, is our first consideration. 
The house shown in the picture is 24 feet long and 12 feet deep. 7 feet high in front and $41 / 2$ feet high in the rear. The foundation is of concrete, made by mixing two parts sand and three parts good bank gravel with one part Portland cement. This wall rests on a footing of rocks, filling a trench three feet deep. In excavating for a trench always be sure to go below the frost line. so that the water that seeps into it in the winter may soak into the ground. The house has a dirt floor.

In the construction of the frame $2 \mathrm{x} 4$ joists are used. The sills are $t x+$, but no other heavy timber is employed. The uprights are placed three feet apart, and the roof timbers 30 inches. The frame is covered with pine or hemlock boards, and there is a dirt floor.

The roof is double pitch, with one side much longer than the other. The rafters in the short pitch are 3 feet long and those in the long pitch 10 feet. The distance from the floor to the highest point of the roof is a little over 8 feet.

The house faces south, as all poultry houses should. There are in front two windows of glass, each light $9 \times 12$. These windows are made in one piece and are what is known in the East as "storm windows." They are screwed to the frames and are not intended to be removed. There is also one of these glass windows in the east end. This gives a splendid distribution of light, and the house has sunshine all the day long. The windows are set 20 inches from the floor. Besides the glass windows there are two windows for the admission of fresh air, each 4 feet long by 3 feet high. These windows are covered on the outside with poultry wire, and on the inside there are frames made of 3 -inch stuff and covered with 10-ounce duck. These frames are so arranged that they may be swung up and fastened to the roof during the day and closed and buttoned at night, or in stormy weather. As a matter of fact, for eight months in the year the frames are fastened to the roof and are not let down at all. The reader will perceive that I believe in plenty of fresh air for hens.

The arrangement of the interior is very simple. There is a roost platform 16 feet long and $3 \mathrm{r} / 2$ feet wide on the back side. This platform is $2 / 2$ feet from the floor, and the perches are eight inches above it. The platform is boarded in at the west end, and if one desires he can arrange a curtain to drop down in front of the birds when they have gone to roost at night. 


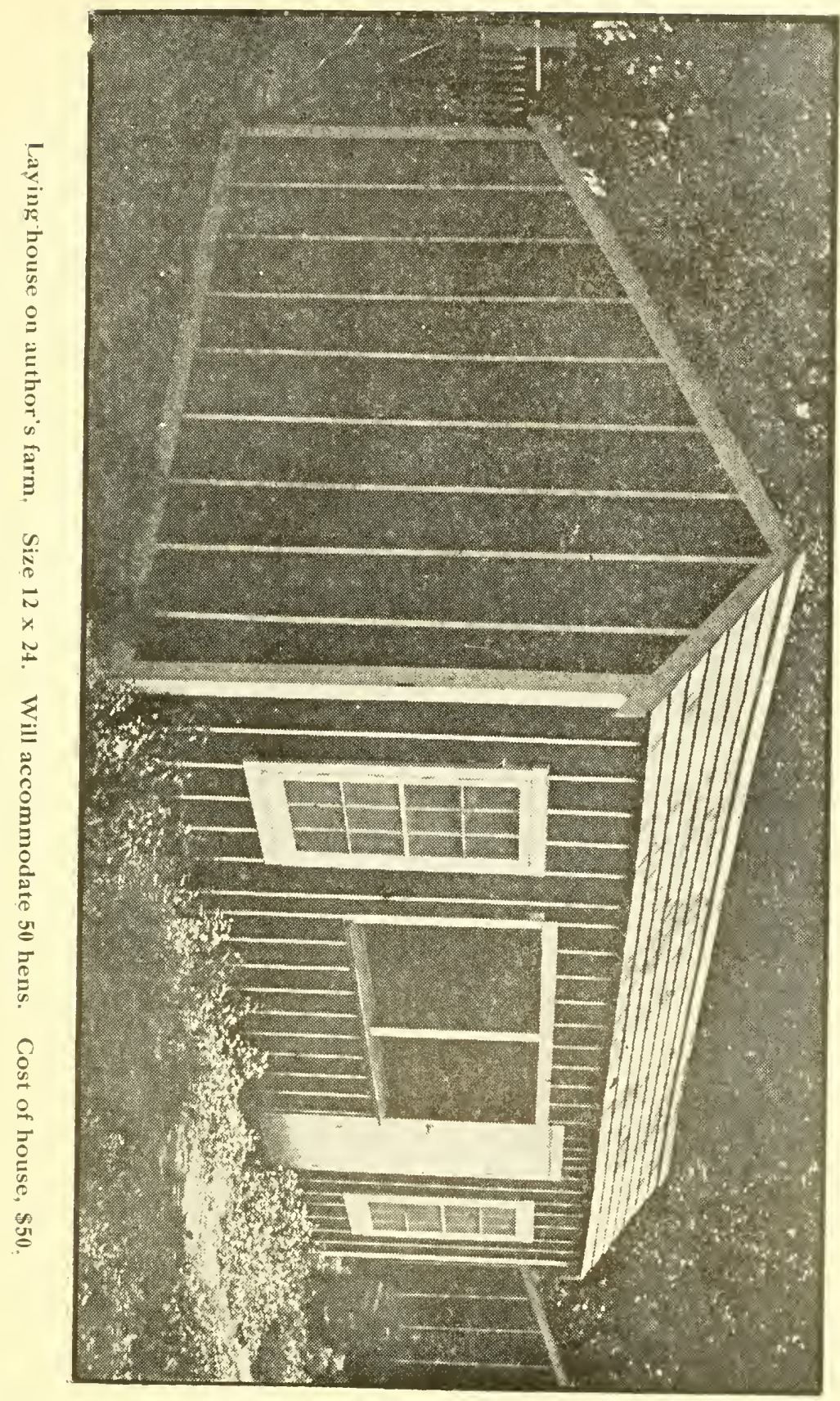


Running along the west end of the house is a platiorm 18 inches high and 24 inches wide. This platform is for the nests. Formerly 1 placed the nests under the rost platform. as is commonly the case, but this required so mucl stooping and pulling out of nests to gather the eggs that I lecided to introluce a nest platform, and find it a great convenience. The nests are up off the floor, out of the way. and are easily accessible to, both the laying hen and the owner.

The only other furniture in the house is two shelves six inches from the floor, one for the grit and shell box and the other for the feed hopper. It will be seen that every inch of floor space is available for scratching and exercise.

The sides and ends of the house are covered with Neponset roofing, painted soom after being put on, and the roof is shingled. A saving in cost might be effected by corering the rouf with Nepunset, painting it, and then in a few years after, when the Neponset begins to wear through, putting on shingles. I have tried many things, but I have never found anything so good as shingles for a roof. Next to shingles I put Paroid, which is easy to apply and will last for years.

The cost of this house, exclusive of labor, is about $\$ 60$. It will cost more in localities where lumber is high.

\section{HOUSE FOR YOUNG STOCK.}

Desides houses for his laying hens, every poultryman needs at number of houses for his goung stock. Is a general thing these houses are quite cheaply constructed, and I have known a breeder to rear prize wimners in old piano boxes. But where a man is not too greatly cramped for means, it will pay him to put up good. substantial buildings for his roung stock. 'They will last longer and be more satisfactory. There is a time in the fall when every breeder is crowded for romm, and these houses which I am about to describe will come in handy for supplementary quarters.

The huluses for young stuck are each 12 feet long by 8 feet wide, $7 / 2$ feet in front 1 y 5 feet in the rear. The sills, plates, rafters, studs and floor timbers are all of $2 \mathrm{xt}$ stuff. and I put in enumglo to make a stiff frame.

The floor is domble, and is made of boards. The roof is single slope or shed romf, as it is called.

The foundation for the house is made of old railroad ties. Instead of setting the ties in the ground, as is the case with many poultry houses, the ties are sawed into sections 16 inches long and laid down upon the grass and the sill laid upon 


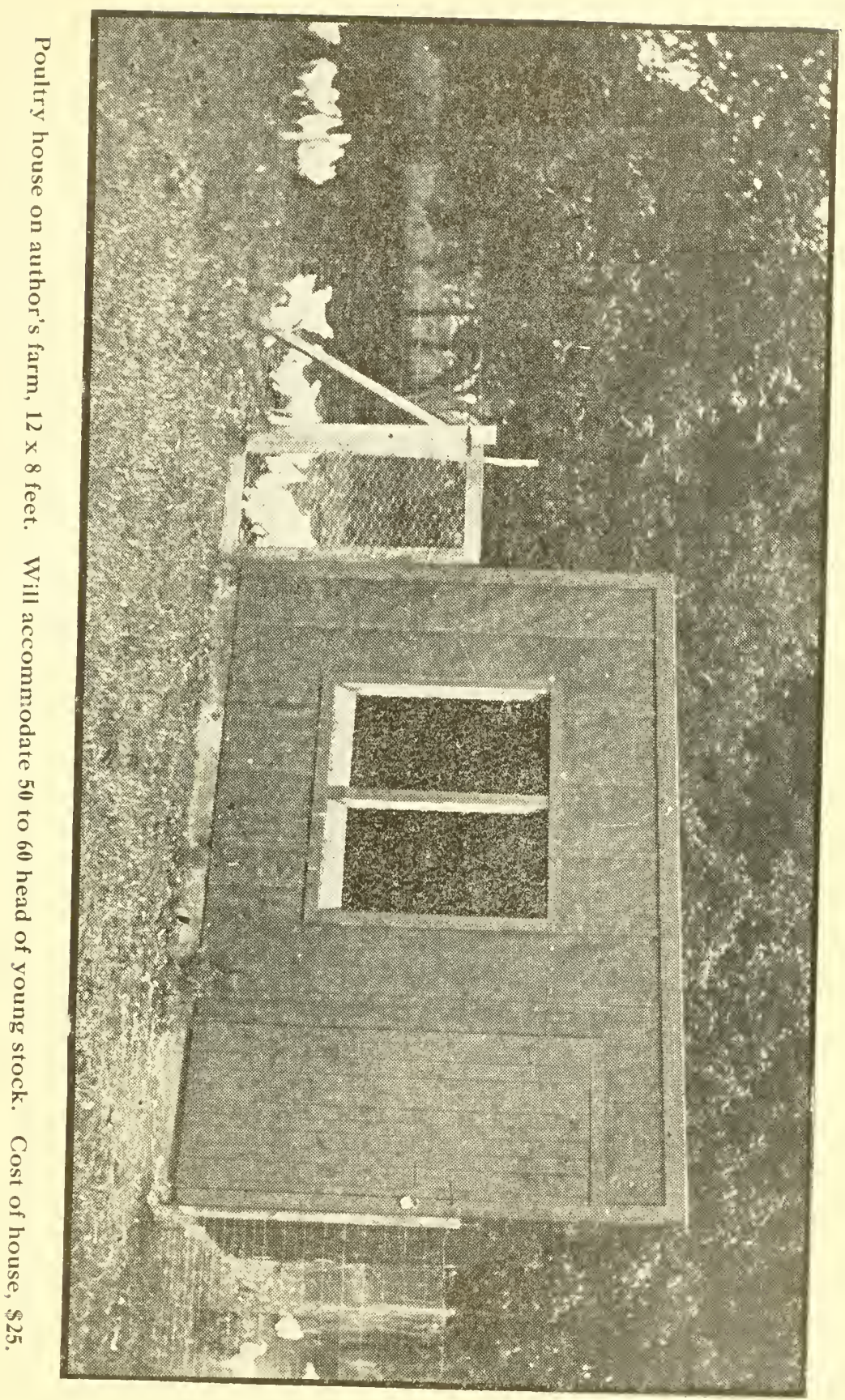


then. For a light house this answers all right. It also makes it convenient when one wishes to move the house from time to time to get it on new soil.

The house is covered with Neponset put on over sheathing paper, and the roof is covered with Paroid. Both sides and roof are kept carefully painted to protect the paper.

I ought to have added to my description of the laying house that I use some kind of lining or sheathing paper under the Neponset siding. One cannot have a poultry house too wind proof and free from draughts.

In the house for young stock there is no glass window in front, but its place is taken by an open window, 4 feet by $t$, divided into two parts by a joist or scantling. This window is covered with poultry wire and is fitted with a curtain which is tacked to a frame. The frame is fastened to the upper joist by three back-flap hinges and the greater part of the time is swung up and hooked to the roof. As the house is used principally in warm weather, the curtain is kept hooked up the greater part of the time, and is only let down and fastened during a storm.

The frame for the curtain is of three-inch boards, with a support running down the center. As the house is not intended to be used in the very coldest weather, the covering for the frame is not of duck, but of cotton cloth.

As the house would be somewhat dark with the curtain down, if there were no other means of admitting light. I have inserted a single window in each end. The windows are what are known as cellar windows and have three lights each, the squares of glass heing 10 by 12 inches: they cost 50 cents apiece.

The following is an estimate of the materials required: llemluck boards. $56+$ feet: spruce joists, 2xt, 218 running feet: spruce joists, 2x3 (roosts), 2t running feet: matched pine for (hors, 20 feet; finish, 3-inch, ro feet: finish, t-inch, 60 feet: Xeponset ruofing, 250 feet: sheathing paper, 250 feet: Paroid. 110 feet. Two small windows for ends, hardware, sheeting. etc. The cost of this house, where a man dues his own work, is nut far from $\$ 25$.

I make use of these louses from Narch up to about Christmas. After the young stock is removed from them in the fall or early winter, they are thoroughly cleaned and disinfected, and the floor is covererl with fine gravel or sand. The house is then allowed to rest until needed for the chicks 
in the spring. When taken from the incubator they are put into these houses, 50 to a house. When the chicks are six or eight weeks old, the brooder is removed, but the chicks are allowed to remain. When they are 8 or 10 weeks old, low perches or roosts are introduced, and the chicks encouraged to use them. When the cockerels get old enough to begin to pay attention to the other sex, they are separated from the pullets and put in houses by themselves.

The pullets are allowed to remain in their houses until they begin to lay, when they are removed to their permanent quarters in the laying house. Sometimes, however, when I am crowded for room, the pullets are allowed to stay longer. even up to Christmas. But I like to get them into the laying house as soon as they begin to lay, for any interference with a laying hen has a tendency to check egg production.

\section{YARDS.}

In my opinion too much space is often given to yards, and valuable land devoted to the purpose which could be better utilized in growing crops. Unless the yard is large enough to maintain a stand of grass in spite of the depredations of the fowls, there is no particular need of going to the expense of wiring in a large space; for if you have watched hens in confinement you have doubtless noticed that they restrict themselves to a comparatively small area. They need a place for dusting, for exercise, for outdoor enjoyment, but it need not be large.

Shade is a necessity in the yards, and if it is not provided naturally it must be artificially. Remember that it is in the hot season of the year that the hens are outdoors, and they need protection from the fierce lieat of the sun. An apple orchard or a grove of standing timber makes an ideal yard. If there is no shade and trees are to be planted for the purpose, plum and peach should be given the preference. for they grow faster than the apple and give good results.

Yards should rin to the rear of the houses, and not to the front. Where yards run to the rear each house is directly accessible. and one does not have to open and shut half a dozen gates and penetrate a labyrinth of yards to get where he wants to go. I believe that I was the first writer on poultry topics to advocate running the yards to the rear, but now many are falling into line with me.

Formerly it was the custom to run a bottom board along 
the ground, from post to post, to nail the wire to, and also to crown the fence with a top rail; but this practice is no longer followed. It is made unnecessary by the fact that wire is now manufactured with horizontal strands running the whole length, and with meshes smaller at the bottom than at the top. This wire does not sag or buckle and follows the contour of the land.

Posts should be planted one rod apart. Aside from the corner posts, which are subjected to considerable strain, large posts are not needed. Small, cheap posts, which can easily be inserted in the ground by means of a bar and sledge, are as good or better than expensive posts of cedar or chestnut. loung pines that have died on the stump from too close crowding, make excellent posts, and may be bought for about five cents each. Removing the bark and dipping them in hot creosote up to about six inches above their ground line greatly increases their durability. It does not pay to spend much time and money upon the construction of the yards, for the wire should be removed every few years and the ground ploughed up and planted to renovate it. 


\section{CHAPTER V.}

\section{Incubation and Brooding.}

It is still a debatable question whether on a small plant it pays to install an incubator or not. There is something to be said on both sides. Where one uses a machine he has things his own way. He does not have to wait for the incubator to get broody, and need have no fear that it will break eggs or yuit before the chickens are hatched. On the other hand, not every man can afford to lock up good money in a machine that is to be used only thrce months in a year. Then, too, an incubator is not a toy for a clild to play with, but a machine with delicate adjustments; and for best results one needs good judgment. experience and to be something of a mechanic. On a large plant incubators are indispensable, but on a small plant it is possible to get along without them. Still. as a man's business grows he will naturally turn to artificial incubation and brooding, and in what follows nuy find suggestions of great value.

\section{SELECTING AN INCUBATOR.}

I receive many letters in the course of a year from persons who wish to know what is the best make of incubator. In reply I tell them I do not know, but can tell them the name of the one I run. I suppose there is no best. There are a dozen incubators on the market, any one of which will do good work. "It is the man behind the gun," we used to say during our war with Spain; and it is the man behind the incubator who is responsible for success or failure. The man who gets a 90 per cent hatch with one machine could probably duplicate it with another if he should try.

The best size for a machine is probably somewhere about 200 eggs. A 50 per cent hatch is regarded as a good one for an incubator. This will give a man 100 chicks at a run. If he wants fewer he can put in fewer eggs, and if he wants more he can get another machine. A 200-egg incubator may be run with 100 eggs, but a 100-egg machine cannot be run with 200. It takes little more oil, if any, for a 200-egg inculator than for a smaller one, no more time to attend it, and 
the 200-egg machine is generally more satisfactory. On the other hand should the hatch go wrong, as will sometimes happen, 200 eggs are enough to spoil; and for this reason 1 do not recommend the purchase of extra large machines. The 200-egg incubator is the standard.

\section{FOLLOW INSTRUCTIONS CLOSELY.}

Accompanying each machine as it comes from the factory is an illustrated chart showing how to set it up and a book of directions for operating it. Follow the instructions closely. It's a difficult thing to beat a man at his own game, and the incubator makers have been at it for years. 'They are more anxious to have you succeed than you are yourself, for success means that you tell your friends about their machine and so influence future buyers. They ought to know their own machine. Set the incubator where the temperature is the most uniform, least subject to variations. A cellar is the best or the worst place. A cellar that is moderately moist and contains no artificial heating apparatus is the best place for an incubator, and a cellar with a heater or furnace about the worst. After you get the incubator adjusted rum it two or three days before putting in the eggs.

\section{SOME INCUBATOR CAUTIONS.}

You will trim and fill your lamp once a day and turn the eggs twice; but after doing these things the less you touch your incubator or go near it the better. There is a weird fascination about an incubator, and one can hardly leave it alone. But the less you monkey with it the better. 'This is especially true in latching time. The thermometer will do all kinds of stunts, and you will be tempted to keep your hand un the regulator. But if the incubator has been running well through the hatch, let it alone. After the eggs are through hatching it may be well to open the door and quickly remove the egg trays. This will give you a better chance to see the clicks and will give them more room.

The thermostat may need slight adjustment several times during the hatch. 'The best way to see the thermometer is to use an egg tester to flash light into the machine. This should be done every morning and night before you turn the eggs. 


\section{INSURINCE.}

Before you start in to run an inculator in your house secure a written permit from your insurance agent to do so. There is very little danger of fire from an incubator, and the company would probably indemnify you even if there were no such addenda to your policy. liut it is better to be safe than to be sorry. Most companies grant such a permit upon application. while a few refuse to do so. If you are insured in a company of the latter kind the only thing to do is to surrender your policy and take wut another in a more progressive concern.

\section{TESTING THE EGGS.}

liggs should be tested at the end of the serenth and again at the end of the fourteenth day. In the first test all infertile eggs should be remored. These may be told by the fact that they are perfectly clear, while the fertile eggs show a dark spot from which radiate red, spidery lines. An air cell alsw has begun to form. In the second test it will be found that some of the germs that began to develop have died, and these eggs should be taken out. A little practice will soon enable one to distinguish a fertile frum an infertile egg, and to tell whether the egg is incubating satisfactorily or not.

THE, MOISTLRE PROBIEM.

Why is it that the best incubator made will selkom hatch as large a per cent of the eggs as a hen? The common idea is, lack of moisture. Incubator manufacturers say otherwise. They say that the air constantly circulating around the eggs supplies moisture, and that no artificial moisture is necessary I said just a moment ago that the reader should follow the instructions of the manufacturer carefully and not think he can beat a man at his own game. But in the matter of moisture I am inclined to make an exception-I believe there are times when moisture may be supplied to advantage.

I certain amount of evaporation is necessary from the egg. whether in an incubator or under a hen, or the air coll will not form. and the chick will die. But if evaporation is too great the chick becomes weak and shrunken and the menbrane inside the shell tough and leathery, so that when the period of incubation is completed the chick cannot extrude. itself. The problem, therefore, is to keep the air cell the right. size. A good way for the beginner is to set some eggs under 
a hen at the same time he starts his incubator, and whenerer he tests the eggs in the incubator to test those under the hen. If the air cell in both eases is the same size, the moisture problem is taking care of itself. Put if the air space in the eggs in the incubator is much larger than the air space in the eggs nuder the hen, evaporation is too rapid and should be checker. Mioisture may be supplied by means of water in shallow pans set mnder the egg trays, by a wet sponge introduced int, the incubator, by shallow boxes filled with wet sand, or by sprinkling the eggs with water of the temperature of 95 degrees.

\section{VENTIL.ATION.}

Closely connected with the subject of moisture is the subject of rentilation. During the first four days of incubation the germ will develop with very little ventilation. After the fourth day the air cell hegins to form, and then more rentilation is necessary: on the seventh day the germ requires treatment according to local conditions; in cold weather, more heat and less rentilation: in warm weather, less heat and more ventilatien. At an altitude of 500 or 1000 feet, more rentilation; at an altitude of 4000 feet or more. less ventilation. In extremely dry weather or in a high altitude, about the same quantity of ventilation is required the third week as during the second."

REMOTING CIICKS TO THE ISROODER.

Chicks may be allowed to remain in the incubator for 24 hours after the last one has come out; they should then be removed to the brooder. Meanwhile the brooder should have been got in readiness. If it has been used before it should be washerl out thoroughly with warm water and carbolic acid soap. The lamp should be cleaned and the burner boiled out. A new wick should be put in. After the brooder has dried out carpet the floor with half an inch of sand or soft earth and then start the lamp. The brooder should be thoroughly warmed up before the chicks are put in.

The temperature under the hover should be 95 when the chicks are introduced, and should be kept at 95 the first week. Then it may be reduced a degree a day until it gets down to 70 . Some men use no thermometer, but can tell whether the temperature is right by the action of the chicks; if they bunch together they need more heat; if they spread out and appear contented the temperature is right. 


\section{MANAGEMENT AND CIRE, OF BROODER CIIICKS.}

Pronder chicks come out from one to three months earlier than chicks raised in the natural way, and consequently the mortality among them is likely to be greater. The brooder itself slumld be kept clean. Fivery few days the litter should be renoved and replaced with fresh sand or earth. The chicks should be given as much liberty as is consistent with safety. They should be let out of the brooders into the brooder house. It will be necessary to make a little fence of boards aruund the brooder for the first day or two after they are let out. and to guide the little things back into their house when they begin to show signs of being cold. But they soon learn. Ind in a short time they may be allowed to go in and ont at their own free will.

It is a good plan to keep the floor of the brooder house covered with sand or earth, and to sprinkle it from time to time. There is such a thing as having the brooder house too dry. Notber Earth has a natural moisture which must be reproduced in the bronder house if the chicks are to do their best. Not over 50 chicks should be put together.

\section{HOIV TO FEED.}

The clicken business has been relieved of much of its drudgery by the introduction of the dry feeding method. The poultryman throws in a few handfuls of chick feed four or five times a day, and the chicks do the rest. But there is room for a few suggestions even luere. Chicks need vegetables to balance the grains of which the chick feed is composed. A blood beet cut in two or a mangel will be eagerly attacked. The lieart of a cabbage is good. Onions chopped fine are relished. A handful of beef scraps scattered over the floor once a day will be found and devoured. It is a good rule never to give little chicks more chick feed or cracked corn at a time than they will eat up clean.

I find it a good plan after the chicks are three weeks oll to keep before them all the time a mixture nade up as follows: Bran, two parts; ground alfalfa, two parts; bone meal, one part; a little salt, a little charcoal. This is fed dry, and is in addition to the chick feed and regetables. I also ought to add that I keep clean, cool water before my chicks from the very start.

W'hen $11 y$ chicks are six weeks or two months old then I let them out into their yards. From now on I use the hopper 
system of feeding, and keep feed before them all the time. In one compartment of the hopper is a dry mash made as follows: Two parts gromud alfalfa, two parts mixed feed, one part beef scraps, a little salt, a little charcoal. The ingredients are compounded by bulk rather than by weight. In the other compartment of the hopper I keep cracked corn. In their yards the chicks find grass, bugs, worms, and later in the season apples, peaches and plums. As soon as practicable I separate the sexes, and always aim to keep chicks of the same size together.

\section{BARTON BROODER SISTEM.}

Where one desires to get out chicks early and in large numbers, something like a brooder system is necessary. Brooders such as are sold on the market do not do their best work with the thermometer at zero; they are intended for a milder temperature. When used in mid-winter they need to be kept in a louse in which there is a fire. Consequently on large plants where extra early chickens are wanted, they are generally raised in large brooder houses in which the pipe system has been installed. But this is expensive. Not erery man feels capable of rumning a steam heater. Under the pipe system the mortality is likely to be large at best, and in case of an accident a man may see all the chickens he has on hand perish in a few hours. A system less expensive than the pipe system and where the unit is the individual brooder would seem to be what is wanted in the poultry world.

My friend, Mr. O. P. Barton of Seabrook. N. H., has devised such a system, and when its merits are known it is likely to supersede all others. I description of this system will be worth many times the price of this book to anyone interested in artificial incubation and brooding.

Mr. Barton has lately built a new brooding house in which his ideas are more fully worked out than in previous ones, and I feel that I can best explain the system by describing the new brooder house both outside and inside.

The brooder house shown in the cut is $16 x 40$ feet, and runs north and south. It has five-foot posts, and the height from the sill to the apex of the double roof is 10 feet. The sills are of $4 x 6$ stuff, but all the studding, plates, rafters, etc., are $2 \times 4$. The floor is of earth. The building is covered on the roof, sides and ends with a patent roofing.

IThat impresses one most about the building when he sees 


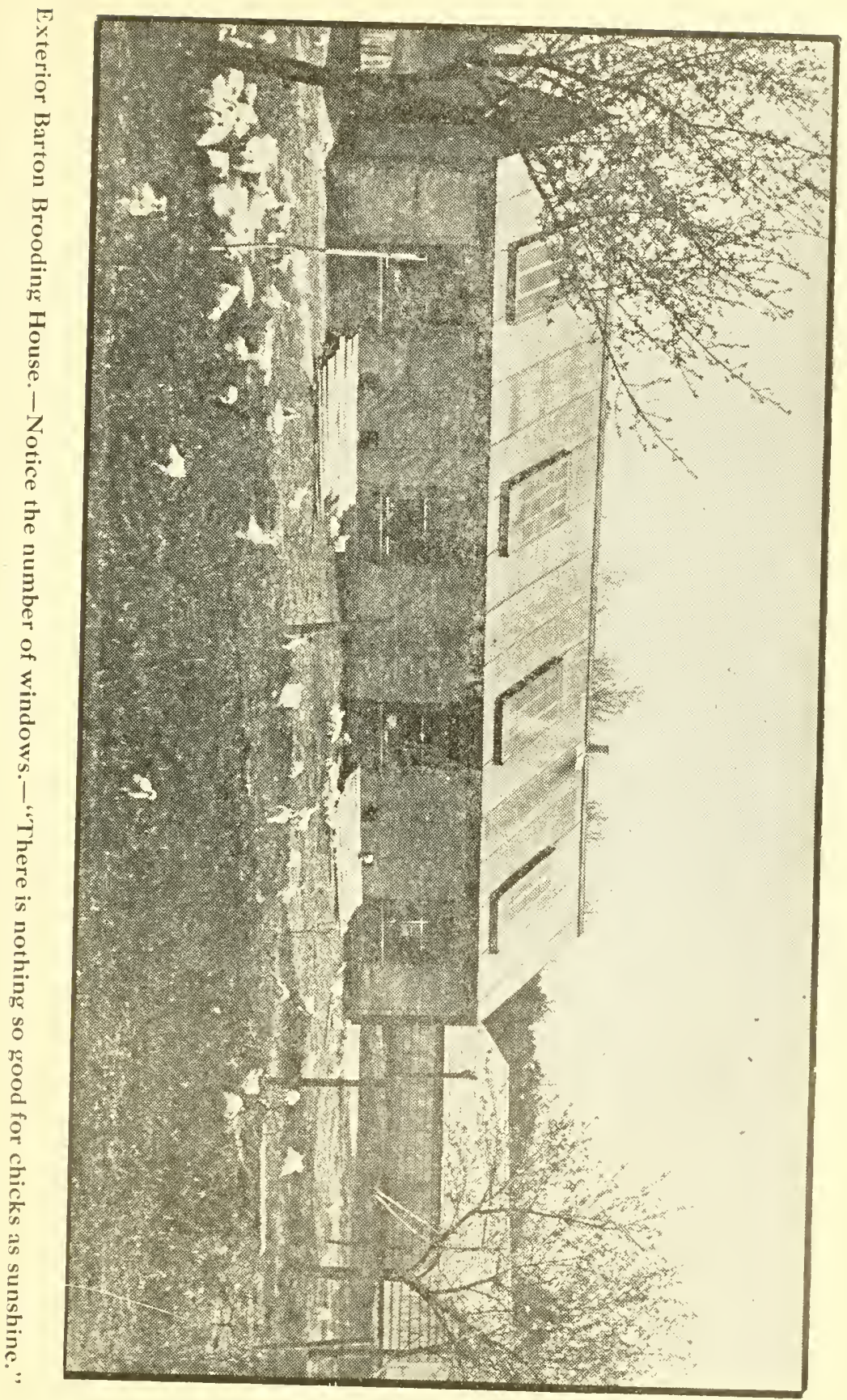


it for the first time is the number of windows. I don't know whether Mr. Barton is a member of the Masonic fraternity or not, bnt he certainly believes in light. "There is nothing so good for chicks as smmshine," he says. There are 19 windows in the house, if I have counted right-four on each side, four on each side of the roof, two in front, and one in the rear. The side windows are half windows, each with six panes 10x1s; the roof windows are each four feet ten inches long by two feet eight inches wide; the front and rear windows are also of generous size.

Opening the door in the south end one steps inside, and if the season is winter the transformation is remarkable, for we are in a place where sunshine, warmth and life hold carnival. Running the whole length of the house is a central walk or aisle, a little over five feet wide. At the north end there is a stove, in which, however, fire is kept only in the most Arctic weather. On both sides of the aisle there are two tiers of shelves, which make one think of the bunks in a logging camp, or, better, the exhibition pens at a poultry show. These shelres are divided into compartments, each containing 53 1-3 square feet. Each compartment is 10 feet long and five feet four inches wide. Each compartment has a board floor and is enclosed by a wire frame or fence two feet high, so arranged that it can be raised or lowered at will. When in place the fence is secured by wooden buttons.

There are four of these pens or compartments in each tier, and as there are two tiers on each side, there are 16 pens in all. As each pen will hold comfortably 50 chicks, the capacity of the house is therefore 800 chicks. But as it is not intended to hold the chicks more than six weeks it can be used two or three times in a season. Mr. Barton estimates that in a house like this he can brood 2400 chicks from January to July.

The hovers themselves are of the very simplest construction. Those in the upper pens are two feet three inches square, and those in the lower pens two feet six inches. They are made of narrow matched boards, beaded and mortised together, and are set on wooden legs-those in the upper pen five inches high and those in the lower six inches. The curtain is of thin oilcloth. Mr. Barton uses a double curtain, or rather two curtains, so arranged that the flaps "break joints," so as to retain as much warmth as possible under the hover.

Heat comes from a lamp set on a little shelf directly under 
the center of the hover. The shelf is secured by iron straps running from the shelf to the floor above. The lamp is an incubator lamp with an "indestructible" glass chimney.

Above the chimney a circular hole is cut in the floor of the brooding compartment, four and a half inches in dianeter. and this hole comes under the exact center of the hover. This hole is protected by a tin collar, which projects an inch or two above and below the floor of the compartment. Above the tin is a circular chimney or heater made of fine meshed wire and extending upward to within an inch of the roof of the hover. Above this a tin plate is tacked to the hover to protect the wood from too great heat.

Chicks are taken from the incubator and placed in these compartments, and in a surprisingly short time they learn how to adapt themselves to their surroundings. Mr. Barton uses no thermometer, but turns on more or less heat according to the weather. At first it seemed to me a mistake to use no thermometer, but now I have thought it out I can see why none is needed. The heat under the hover must vary in degree according to the distance from the chimmey or heater. being considerably greater near the center than at the edges. Unlike other hovers that I know anything about, the center. of the hover is the lightest part, and this naturally attracts the chick as he seeks shelter. As he becomes warm he retires further back, and in this way is always able to find a temperature that suits his needs.

It will be seen that this brooder of Mr. Barton's violates several principles that have been considered well established. The fumes of the lamp pass directly up into the hover, but the chicks seem to suffer no ill effects from them. Indeed a healthier or happier set of youngsters it would be hard to find. I know many men who have made a study of artificial incubation, but I never met a man who can get such a growth on chicks in a given time as Mr. Barton.

The cost of the brooder house and equipment described here was $\$ 150$, but it is doubtful if it could be duplicated under $\$ 200$. But even at $\$ 200$ it is the cheapest and most practical brooder system that the writer knows anything about.

\section{HATCHING BY HENS.}

The sitting hen should have a quiet, sequestered place where she can spend the time of her confinement, and be 


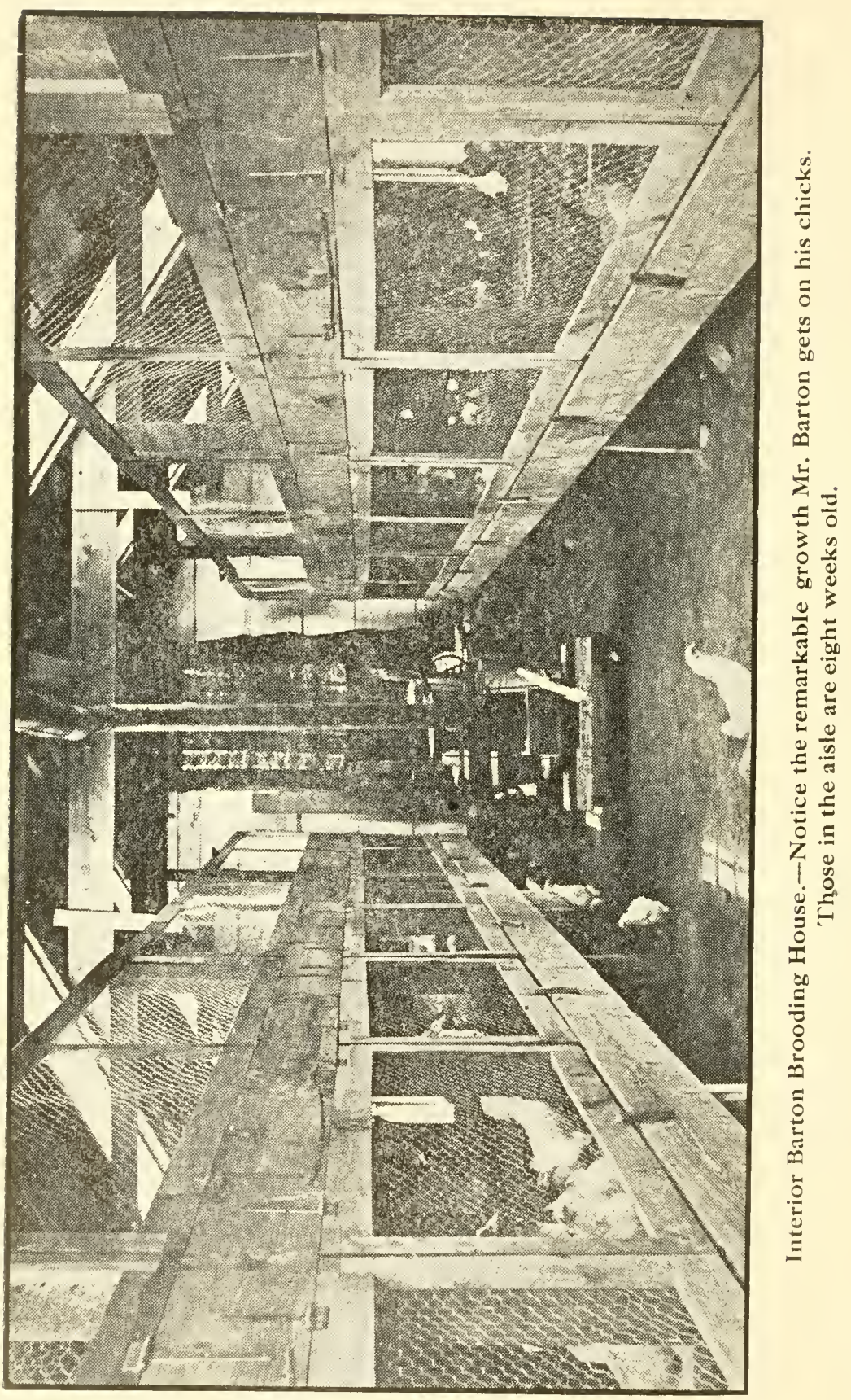


made as confortable as possible. The best place is a room devoted entirely to the purpose. 'This room should be scrupulously clean; the walls should be whitewashed, the cobwebs swept down, and there should be good ventilation. In the center of the room there should be a commodious dust bath, and a dish of water should be always accessible. There should be a hopper somewhere in the room, one compartment filled with whole corn and the other with good sharp grit.

Procure of your grocer as many boxes or crates as you expect to have sitters, and let these crates or boxes all be of the same size, if possible. Set them on the floor, close to the walls of the room, side by side. Take a strip of two-inch "furring" and nail it to the joists back of the boxes at a height two feet from the floor. Take another strip and run it parallel with the first, but two feet or so from it, nailing the ends to the studding or uprights. Lirace this second strip of "furring" in the middle by a strip rumning to the floor. You now have a long, narrow frame of wood above your nest boxes. On this frame tack "shorts" bags or strips of burlap, so that a roof is formed above the setters, and let the "shorts" bags hang down until they reach the top of the nest boxes. You have now covered the boxes with a canopy such as used to be erected over an old-fashioned bed, and shut up the sitters in semi-darkness. They are much more contented and sit better than in the bright sunlight. This frame or canopy may be continued all around the room, and as many as fifty hens may he set in a room twelve feet square.

Care of the Sitters.-.'The hens that are intended to be used for sitters should be taken off the nests at night and conveyed carefully to the "maternity ward" described in the preceding paragraph. The best material I have ever found for nests for sitting hens is tobacco stems; the pungent odor from these stems is death to lice. The nest box should be filled half full of tobacco stems and three or four glass eggs placed in the new-made nest. The sitting hen should be placerl in position and left for the night. If she continues broody and shows a disposition to stick to her job, the next night it will be safe to entrust her with real eggs. Cive her as many eggs as she can comfortably cover-from eleven to fifteen, according to the size of the hen and the nature of the season.

When the preparations have been made in advance for the 
comfort and convenience of the sitting hen, really there is very little for the attendant to do. The hens should be examined from time to time to see that no eggs are broken under them, and if a hen shows a disposition to stick to her nest too closely she should be lifted off every day and made to remain away a short time. Where eggs are broken in the nest, the soiled nest material should be removed and the smeared eggs cleansed in tepid water. A few days before the eggs are due to hatch, the tobacco stems should be removed and a new nest made of soft hay for the little chicks. The hen should at this time be given a thorough dusting with insect powder.

Testing the Eggs.-Figgs should be tested under a hen as well as in an incubator, and the infertiles and eggs with aborted germs should be removed. The first test should be made when the hen has set seven days. Procure an egg tester at a poultry supply store, or make one for yourself, and examine all the eggs under each hen. The infertile eggs will be perfectly clear when exposed to the concentrated light, while the eggs that have begun to hatch will show a dark spot. The infertile eggs should be removed, and the fertile ones put back. Now appears the advantage of having a number of hens sitting at the same time; for if enough infertile eggs are found to warrant it, one or two of the hens can be started in again with new eggs, while enough fertile eggs are placed under the remaining hens to make up the original number.

The second test should be made a week later and is a repetition of the first. The germ has grown much larger and now fills the greater part of the shell; there is an air-space at the big end. In some eggs the germ has died. These eggs can easily be detected and should be removed or they may explode under the hen.

Care of the Chicks. - The chicks should be allowed to remain in the nest about 24 hours after the last one hatches out, and then chicks and hen should be removed to some other location. If it is early in the season and the ground is still damp and cold. I would advise putting them in a little house, the floor of which has been carpeted with sand, and where there is every convenience for their care and comfort. If you have followed instructions and tested out all infertile eggs and eggs with dead germs, and made up the quota with good, 
hatchable cggs, each hen should have from 13 to 15 lively chicks under her charge. If the hens have been together in the same room during the incubating period as many as four hens with their broods may be placed in the same room. If they become so unladylike as to quarrel, they may be tethered so that they cannot do each other or themselves any serious harm. The chicks will run from one hen to another without discrimination, and it may be necessary to divide the flocks at night so that each mother may have her share.

In a chicken house large enough to hold four hens and sixty chicks the chicks may be allowed to remain for several weeks. In the house they are safe. Rats cannot get them; cats must leave them alone; the migrating havk cannot seize them in his talons. Early hatched chicks may be allowed to remain in the house for six weeks to advantage, unless the weather is exceptionally fine. 


\section{CHAPTER VI.}

\section{The Laying Stock.}

When a breeder sends ont a consignment of eggs or stock he must often wish that he could send some of his experience alung at the same time: for unless the customer understands the elementary principles of poultry keeping he will come to grief. Breeders often get blamed for what is not their fault. The number of things a man needs to know is not large; but he needs to know them so well that it will become second nature for him to do them.

\section{SELECTING THE LAYERS.}

It is highly important that we put into our laying pens only birds that will give a good account of themselves in egg production; otherwise profits will be cut down to the vanishing point. The first 75 eggs a hen lays in the course of a year go to pay her feed bill; all she lays above 75 is clear gain. It will be seen, therefore, how necessary it is that we eliminate all weak layers from the flock and retain only the most prolific. Where there is a hen that does not lay, there is another hen somewhere scratching her legs off to pay that hen's board.

How can we select the good layers and reject the poor rnes? The trap nest is the only infallible way. The trap nest is very valuable, especially for a beginner. After a man has had more experience he can get along without it. But for a beginner the trap nest is almost indispensable. I quote from the letter of a correspondent: "I killed to-day for our dinner a hen that from the time she laid her first egg in December, 1909, until now (January 19, 1911), has never laid but t2 eggs. She is a full sister to three others, each of which went over 200 eggs in their pullet year."

Early maturity is a valuable indication. The pullet that is to lay from 150 to 180 eggs a year must have twelve months in which to do her work; she cannot do it in less. But there is another reason apart from this. Ovulation, or the production of the egg, is the consummation of the sexual function of 
the female. The more strongly sexed a hen is the more eggs she will lay; the more poorly sexed the fewer eggs. Early maturity is a mark of strong sex development and is to be highly prized in pullets. The evidence a pullet gives by early maturity is confirmed by the trap nest, which shows that earlymaturing pullets surpass their slower sisters as egg producers.

Appetite and assimilation are also tokens. The laying hen is the hungry hen. The hen cannot make eggs without feed any more than the children of Israel could make bricks without straw. The hen that is laying rushes to meet you when you open the door of the house in the morning, scratches industriously in the litter all day for food, and goes to roost late at night. It is the hen with the full crop that lays the eggs.

\section{THE PHYSIOLOGICAL, TEST.}

Besides the tests which the eye and ear supplies, there is a physiological test which is of great value. It is a well-known fact that in all mammals the pelvic bones soften and spread apart before the female is delivered of a child. The same thing is true of birds before the first egg is passed. As the time for ovulation draws near the pelvic bones begin to soften and separate, until they are so far apart that two or three fingers can be laid between them. The pelvic bones are the bones just below the vent. Pick up a young pullet, clasp your left hand around the legs, and hold her under your left arm with her head pointing to the rear. Place your right hand just below the vent, and you will feel two small protuberances close together; these are the pelvic bones. Now select an older pullet and treat her in the same way. You will notice that the bones have begun to spread apart. If the pullet is laying or nearly ready to lay. you can put two, and sometimes three, fingers between the bones.

\section{FEEDING FOR EGGS.}

"What do you feed?" This is a question that is asked by visitors to a poultry plant more than any other. The novice seems to think that there is some magic formula, some secret combination, which, if he can master, will solve all difficulties and make hens lay in season and out of season. This is a mistake. There are half a hundred methods of feeding, each one of which will produce good results. The hen is not a machine; she is a living thing, and she has a power of adaptation and assimilation which no machine can have. 
Many years experience has convinced me that there are two fundamental principles underlying this whole matter of feeding, and these principles are so simple that a child can master them: 1. The hen needs plenty. 2. The hen needs variety. With these two principles held clearly in mind the poultryman need never go astray.

1. The hen needs plenty. There was a tendency a few years back to underfeed. It was believed that if a hen was given all she could eat she would take on fat and become useless for egg production. This belief has been exploded. It is the fat hen that lays eggs. Time after time have I killed a hen that was so fat that she bagged down behind only to find that she was full of eggs and was one of my best layers.

The fact is, in poultry keeping we are getting too far away from Nature. It is a fact that has been remarked by scientific men that the young of mammals and birds are always produced in the season when the food supply is most abundant. A bird needs to be well provided with fat in order to meet the strain of incubation and the confinement of rearing her young. If we employed our hens to hatch and rear our chicks we would not have to worry about getting them too fat, for the surplus fat would be burned up in the way Nature intended.

2. The hen needs variety. In the community where I live hens are kept in the good old-fashioned way. They are allowed to run at large and forage for themselves, and are fed with corn when they come up nights. When the season is mild they often range the fields clear up to Christmas. I have known a snowstorm, which kept the hens in the house, to cut down egg production to the vanishing point, although the inens were laying heavily before. At the same time when in the house they were given all the corn they would eat. What was the cause of the falling off in egg production? Lack of variety in their bill of fare. In the fields the hens found insects which had been killed by the frost, grass that was still green and tender, and many other appetizing morsels; but in the house all these were suddenly taken away. As a consequence, the hens shut down in egg production because they had not the materials out of which to construct their eggs.

My method of feeding is simplicity itself. I use the dry feed method, never mixing up a wet mash. In each pen there is a feed hopper, divided into two compartments. In one compartment I keep mixed feed or bran, and in the other beef 
scraps or fish scraps, replenishing the supply whenever it becomes exhausted. Sometimes, when I think of it, I stir a tablespoonful of salt into eight quarts of mixed feed or bran before I put it into the hopper.

There are three kinds of grain which I use-oats, wheat and cracked corn-varying the proportions according to the seasoll.

In the summer I feed oats in the morning, wheat at noon, and cracked corn and oats at night. I feed a quart of oats or cracked corn to every fifteen hens, or a pint of wheat to the same number.

In the winter $I$ feed corn and oats in the morning, wheat at noon, and corn and oats or corn at night. The colder the weather the more corn I feed. In the winter the grain is thrown into a deep litter and the hens made to scratch for it, but in summer it is given them in their yards and all they have to do is to pick it up.

I also feed a variety of green food, as I shall explain later.

This is my method of feeding, but there are a score of ways as good as mine. Terhaps the most pupular formula is that of the Maine Experimental Station:

Theat bran, two parts;

Corn meal, one part:

Mirddlings, one part ;

Gluten meal, one part:

Linseed meal, one part:

Feef scrap, one part.

Clover leaves or heads to give bulk.

The ingredients are compounded by weight and are thoroughly mixed together. The mash is kept before the hens all the time and they are allowed to help themselves. Wrhole corn, wheat and nats are fed in comnection with the mash.

Another formula that I have used and found very satisfactory is this:

Mixed feed, tivo parts;

Cround alfalfa, two parts;

Corn meal, one part;

Gluten, one part;

Beef scraps, one part;

Salt, charcoal.

Compound by bulk, and not by weight.

Oyster shells should be kept before the hens all the time, 
and their drinking dishes should never be allowed to remain long empty.

\section{COMPLETE, FEED FORMUIAS.}

The International Glue Company of Boston sends out a very valuable leaflet to its customers, containing formulas for all seasons and conditions. The formulas are intended to promote the use of fish scrap. which is manufactured by the Company, but beef scrap can be substituted where fish scrap cannot be obtained, with equally good results.

FEED FOR LAYING PULLETS.

DRY MASH-First month in house-

Bran, 300 pounds.

Corn meal, 100 pounds.

Middlings, 100 pounds.

Fish scrap, 100 pounds.

Second month in house-

Bran, 200 pounds.

Corn meal, 100 pounds.

Middlings, 100 pounds.

Gluten meal, 100 pounds.

Red Star scrap, 100 pounds.

Third month, same as second, with 50 pounds linseed meal.

Fourth month, same as second.

Fifth and following months, same as third month.

One feed each day whole or cracked corn.

One feed each day, equal parts wheat and oats.

FEED FOR OLD HENS AND COCKERELS KEPT AS BREEDERS.

DRY MASH-Until beginning of breeding season-

Bran, 400 pounds.

Corn meal, 50 pounds.

Middlings, 50 pounds.

Red Star fish scrap, 100 pounds.

During breeding season same as pullets in third month.

Dry grain same as for pullets.

\section{FEED FOR CHICKENS.}

SCRATCHING MIXTURE-Chick feed-

Cracked wheat, 150 pounds.

Pinhead oats, 100 pounds. 
Fine screened cracked corn, 150 pounds.

Fine cracked peas, 30 pounds.

Broken rice, 20 pounds.

Chick grit, 50 pounds.

Fine charcoal, 20 pounds.

MASH-

Wheat bran, 40 ponnds.

Corn meal, 35 pounds.

I inseed meal, 5 pounds.

Red Star scrap (fine). 20 pounds.

Alfalfa meal, 5 pounds.

The mash is scalded and then dry rolled oats are mixed with it in proportion of two parts rolled oats to six parts mixture.

From about the third week on a dry mash is used which has at the beginning the following composition and is modified to suit the need of the growing stock:

Wheat bran, 20 pounds.

Corn meal, 30 pounds.

Linseed meal, 5 pounds.

Daisv flour, 10 pounds.

Red Star fish scrap. 10 pounds.

\section{GREIN FEED.}

Green feed of some kind is necessary if the hens are to keep in good health and do their best in egg production. In order for the food to be digested the gastric and pancreatic juices must circulate freely, and where the food is concentrated these juices cannot penetrate easily. Consequently, digestion is not so thorough. Green feed lightens up the mass, and also supplies a mild vegetable acid that acts as a tonic to the system.

Ifter the feed has passed through the crop and gizzard it enters the intestines, and it is passed along by peristaltic action until it is either absorbed or eliminated. It is evident that the intestines can do their work more easily if they have to deal with a soft, moist, porons mass than they can if they have to push along dry. hard, concentrated fecal matter. Thus the health of the fowl demands that the ration shall be bulky rather than otherwise, and that green feed shall form a considerable part of it.

Where hens have a free grass range they will secure their own supply of green feed during the summer months; but 
where they are confined in their pens or shut up to yards denuded of all vegetation, they must be supplied by their owner.

Second-growth clover is an ideal green feed, if it can be produced at a moderate price. It need not be cut up, but may be fed on the stalk, say a bushel a day to every 25 hens: and the stalks may be allowed to remain for litter.

Cabbages are excellent, and so are mangels. Nangels may be grown with little labor, and a small plot of land will produce a generous supply, as they grow to immense size.

Onions are good in limited amounts, but fed too freely they flavor the eggs. Cabbages and mangels may be fed whole, but onions should be chopped.

Boughs from pine trees, nailed to the studding of the house, will furnish the hens with green feed and exercise. They will eat the needles greedily, and the pine needles seem to have a medicinal effect upon the fowls.

SPROUTED OATS- "FEED TEN CEN'TS A BUSHEL."

Some years ago there appeared in the poultry papers an advertisement that attracted wide attention. It was headed "Feed Ten Cents a Bushel." Those who answered the advertisement received a circular which described a book in which the formula for this feed could be found. The price of the book, I an told, ranged from one to five dollars. 'Those who sent the money received the magic formula, and learned that the wonderful feed was-sprouted vats. There was a feeling at first on the part of the purchaser that he had been "stung," that he had paid an exorbitant sum for information of doubtful worth. but as time went on, as he gave the formula a trial, he found that his money had been well invested, that in sprouted oats he had a feed of great value, that five dollars was a small sum to pay for what he had received in return.

I wonder if the fellow who first ran across the idea of spronted oats knew what he had found, and I wonder if one in a hundred who feed sprouted oats knows wherein the great benefit lies. Where oats or barley germinate out of the ground, they produce a chemical substance called diastase, which has the power to convert starch into dextrin, maltose and dextrose. Diastase in digestion has a power similar to saliva. That this substance when consumed by hens or cockerels has the further power to augment fertility in the egg 
there cannot be the least doubt. This is where the great value of sprouted oats resides: eggs will be far more fertile when they are fed. Feed when the sprouts are an inch long, to secure the best results, and not wait until they are longer.

The process of sprouting oats is thus described by Mr. L.

E. Keyser in the Tetaluma Veekly Poultry Journal:

"Take a quantity of clipped or whole oats and soak them in water for $2+$ hours. Then pour off the water and place the oats in a shallow box which has holes in the bottom to let the water drain off. Night and morning water the oats, using a sprinkling pot and warm water. Spread the oats out in the box to the thickness of about two inches. This may be done as soon as the oats are placed in the box, or they may be left in a pile until they hegin to spront; but continue to water them night and morning. In ten days or two weeks, depending on the temperature of the room where they are kept, they will be ready to feed. . . . To feed, cut into blocks eight to ten inches square. By this process one hushel of rats will make about four bushels of feed. . . With oats at the present price. . this feed costs 15 cents a bushel."

Barley is recommended by another writer in the same paper, Mr. N. S. Trowbridge, as a substitute for oats. Barley possesses nearly the same constituents as oats, but as it germinates more quickly is more desirable for use in winter. The method of preparation is the same. The oats or barley should be germinated in a moderately warm room. preferably a cellar.

\section{EXERCISE.}

Laying hens cannot keep in good health and produce the maximum number of eggs without a reasonable amount of fresh air and exercise. They do not need to be kept on the jump from morning until night-a poultry house is not a camp for consumptives-but a certain modicum of fresh air and exercise they must have if they are to do their best work in egg production.

Exercise breaks down the old tissues, which must be replaced with new ones. It is on the new wood that the tree bears its fruit, and it is with the new tissues that the eggmaking organs are stimulated. Where the old tissues are not broken down with sufficient rapidity, the fowl takes on fat, becomes lazy, and comparatively few eggs are produced. 
No matter what system of feeding is adopted, the hens should be made to work and work hard for a part of their ration. To this end the grains that are fed should always be scattered in a deep litter, and the hens compelled to dig them out.

While hens are at work in the house the windows shunld be opened, and closed when they are through. On every pleasant day in winter, when the snow is not too deep, they should be let ont in their yards for a little while. A few minutes' exercise with the snow shovel will furnish the biddies with a patch of bare ground which they will greatly appreciate.

\section{CARE OF THE HOUSE.}

The poultry house should be kept clean and supplied with everything needed for the health and comfort of the fowls. When I speak of keeping a house clean, I speak relatively. I do not expect it to be kept as immaculate as a lady's parlor, but to be kept clean enough so that the health of the fowls will not suffer. The droppings should be removed at least once a week or sprinkled over with land plaster or sifted coal ashes, and the roosts and side supports should be kerosened once a month in winter and once a week in summer. It is a good plan to sweep the walls and ceiling and whitewash twice a year. During the winter the floor should be covered with litter, which should be renewed frequently. In each pen there should be a dust box kept well filled with sifted coal ashes, so that the hens can take a bath whenever they wish to.

"For killing lice upon the walls and roofs of the henhouse there is nothing better than cresol soap, made as follows: Shave one 10-cent cake of laundry soap into a pint of soft water; heat or allow to stand until a soap paste is formed. Stir in one pound commercial cresol and heat or allow to stand until the paste is dissolved. Stir in one gallon of kerosene.

"Cresol is a coal-tar product and may be obtained from the druggists at about 30 cents per pound. Care should be taken not to get any upon the hands or face. as it will cause intense smarting. For use as a lice paint, apply undiluted. When used as a disinfectant through the spraying machine for killing mites, it may be diluted with fifty parts of water, which will make a milky colored liquid." 


\section{GETTING RID OF LICE.}

Lice are easily raised, but are not a very profitable crop. The best way is not to allow them to get a start. Where the fowls are in good health and have access to a dust bath and the house is kept reasonably clean, there ought to be no trouble in holding them in check. The male is the worst offender. He seems to have a constitutional aversion to a bath, and if left alone will soon be swarming with lice himself and distribute them anong the rest of the flock. The poultryman not uncommonly finds that the term "breeding male" has a double significance. "The only sure way to keep lice off your fowls is to dust them with a good lice killer once in a while.

There are many brands of lice powder on the market, but the poultryman can make as good a one as he can buy. Bulletin 179 of the Maine Experiment Station gives the formula for a lice powder that cannot be beaten:

"Take 3 parts of gasoline and 1 part of crude carbolic acid, 90-95 per cent strength, or, if the 90-95 per cent strength crude carbolic acid cannot be obtained, take 3 parts of gasoline and 1 part of cresol. Mix these together and add gradually, with stirring, enough plaster of paris to take up all the moisture. As a general rule it will take about 4 parts of plaster of paris to 1 quart of the liquid. The exact amount, however, must be determined by the condition of the powder in each case. The liquid and dry plaster should be thoroughly mixed and stirred so that the liquid will be uniformly distributed through the mass of plaster. When enough plaster has been added. the resulting mixture should be a dry, pinkish-brown powder having a fairly strong carbolic odor and a rather less pronounced gasoline odor.

"Do not use more plaster in mixing than is necessary to blot up the liquid. The powder is to be worked into the feathers of the birds affected with vermin. The bulk of the application should be in the fluff around the vent, and on the ventral side of the body, and in the fluff under the wings. Its efficiency, which is greater than that of any other lice powder known to the writers, can be very easily demonstrated by anyone to his own satisfaction. Take a bird that is covered with lice and apply the powder in the manner just described. After the lapse of about a minute, shake the bird, loosening its feathers with the fingers at the same time, over a clean piece of paper. Dead and dying lice will drop on the paper 
in great numbers. Any one who will try this experiment will have no further doubt of the wonderful efficiency and value of this powder.

"For a spray or paint to be applied to roosting boards, nest buxes or walls and floor of the hen houses, the following preparation is used: 3 parts of kerosene and 1 part crude carbolic acid, 90-95 per cent strength. This is stirred up when used and may be applied with any of the hand-spray pumps or with a brush.

"If 90-95 per cent crude carbolic acid can not be obtained, cresol nuy be substituted for it in this paint."

\section{SICKNESS IN THE FLOCK.}

Where the laying stock possess constitutional vigor and are kept under sanitary conditions, the amount of sickness will be small. It is a question whether it pays to doctor sick hens or not. Certainly it does not where the treatment must be individual and extended over a long period. But in the case of simple ailments, or accidents, it probably does pay, especially where it can be arranged so that the hens will take their own medicine. In case of sickness it is a good plan to at once remove the afflicted ones to an airy and sunny pen and keep them there until they are cured. Nature is working on the side of health, and hens often get well without their owner's assistance. Still, there are a few common diseases that I find it pays to treat.

Colds, Catarrh, Bronchitis.- 'lhese are the most common afflictions that beset our fowls; they seem to run one into another if left alone. Colds often make their appearance in the fall when the laying stock are taken from the range and transferred to their winter quarters. Sudden changes of temperature affect fowls just as they do human beings. A small crack or opening above the heads of the hens on the roost, which creates a draft, is the cause of many colds. Colds are characterized by sneezing, bubbles in the eyes, and by the sealing up of the nostrils, so that the bird is obliged to breathe through the mouth. There are various simple remedies for colds which are very good. Chopped onions seem to act as a gentle stimulant and often restore the birds to health. A few drops of creolin in a gallon of drinking water is recommended, although the birds do not like the taste and will drink only when driven to it by extreme thirst. A pinch or two of permanganate of potash in a gallon of drinking water is 
excellent. Permanganate of potash may be purchased at any drug store and seems to be the base of the so-called "roup remedies." A few drops of spirits of camphor or of aconite in the same amount of water will frequently abort a cold. For cleaning the nostrils dip a feather in kerosene and tonch each nostril with the tip.

Roup is thought by many to be the result of a neglected cold; by others to be a bacterial disease. Roup is one of the greatest scourges of the poultry yard. The disease is characterized by a peculiarly loathsome smell, which haunts the memory of anyone who ever breathed it, but which makes identification easy. Roup is highly contagious, and the sick hens should be segregated at once. Put the worst cases out of their misery, burn or bury their bodies, give the house a thorough cleaning ont, spray with some good disinfectant, and put roup medicine into the drinking water.

Scaly legs is sufficiently defined by its name. It is contagious, spreading from fowl to fowl, but its progress is slow. A good treatment is to spray the legs with kerosene, repeating the treatment once a week as long as necessary. The scales in time will drop off. Keep the roosts well sprayed with kerosene at the same time.

Crop-bound is the cloking of the passage from the crop into the gizzard, generally by hay or grass which the hen has swallowed. The obstruction must be removed and the passage opened in some way. Begin by giving the fowl a dessertspoonful of olive oil, and after she has swallowed it try kneading the crop.

Sometimes by holding the hen head downwards and gently kneading the crop the contents may be dislodged. If this treatment fails a slight surgical operation is necessary. With an assistant to hold the bird. make an incision an inch long in the upper part of the crop, eutting through the outer and the inner skin. Then with a wooden skewer renove the offending mess, making sure by running in your finger that the passage into the gizzard is no longer obstructed. Sew up the inner skin, using silk thread and making each stiteh complete by itself. Then sew up the outer skin in the same way. Put the bird by herself, and after 24 hours feed lightly on a warm mash mitil the wound heals and the bird is cured.

Liver Trouble.-In the spring the poultryman is quite likely to lose a number of choice birds from liver trouble. The 
comb is the barometer of the bird's condition. When in perfect health the comb is bright red, as in the case of heavily laying females pale but not purple. A purple comb is the signal that the liver is out of order. A teaspoonful of olive oil administered as a laxative is good. But the best treatment is to at once make a change in the bill of fare, feeding less corn and giving more green stuff.

Although I have not spoken very enthusiastically about doctoring sick fowls, yet I believe that every poultryman should have in his library a book on poultry diseases. The study of this book will enable him to recognize the beginnings of disease sooner than he would otherwise, and to take precantionary measures, for in the poultry house it is empliatically true that "an ounce of prevention is worth a pound of cure."

\section{BROODY HENS.}

Where a large egg output is desired, the key to the situation is found in the treatment of broody hens. Broodiness is nature's signal that the vital forces have been drawn upon in egg production and that the hen needs rest. When I find a broody hen on the nest at night, I remove her to the breakingup pen, carefully noting down in a memorandum slip the day of the month and the hen's pen and number. The breakingup pen differs from the other pens only in one particular-the nest boxes have been removed. In this pen the broodies have their headquarters until the fever abates. 'They are fed lightly - not more than one-fourth the usual amount-and are given access to a grass range. Most people are in too great a hurry to break up sitting hens. Do not bother them, but let them take their own time. In a week or ten days they will be cured. 


\section{CHAPTER VII.}

\section{The Selling End.}

The great problem which confronts the farmer in these lar's is how to get his share of the consumer's dollar. The farmer can raise any anount of truck. 'There are books and reports that will tell him how to increase the product of dairy, farm and field. Put when it comes to disposing of the product it is different. There are no books and reports that will help him here. The problem is one he must work out for himself. All cuncede that too large a proportion of the farmer's profits goes to the middleman.

The loss to farmers the country through is simply stupendous. The farmers of this country in 1910 received $\$ 8,000$,000,000 for their products, while the consumers the same year paid hetween $\$ 13,000,000,000$ and $\$ 14,000,000.000$ for the same commodities. In other words, the farmer gets only 60 cents of the consumer's dollar. It is not the high cost of living but the high cost of selling that troubles the farmer.

\section{CUT OU'T THE MIDDLEMEN.}

The poultryman is in the same boat with his brother farmers: ton great a proportion of his profits goes to the middlemen. Pack from the cities the poultryman sells to the collector, the collector to the commission merchant, the commission merchant to the wholesaler, the wholesaler to the retailer, and the retailer to the consumer. Here are five profits to be made. If the farmer could only cut out these middlemen and deal directly witls the consumer, he would be infinitely better off.

\section{THE SIDE-LINE POULTRYMAN.}

It is here that the side-line poultryman has his great advantage-he deals directly with the consumer. It costs him 110 more for feed than it does lis brother back on the hills a lumdred miles from market, and he gets at least one-third more for his product. It is for this reason that I so strennously advocate poultry keeping as a side line. The poultry papers are full of descriptions of big farms; the ideal to be 
aimed at is a farm deroted entirely to poultry keeping. It is a mistake. The fellow who is the best off is the fellow who has a city lot with a cliance for poultry in the back yard or a little place just outside the city within the fire-cent electric car fare zone, and who puts in his spare time with his fowls. He does not have enough to do on his place to feel burdened, and he can add two or three hundred dollars each year to his income with but little effort. The hens will pay the rent or pay for the place if he wants to buy.. IJe can take his eggs and fowls to måket when he goes to work, and not nulikely sell to his shopmates or his employers for a good sum.

\section{BUILDING LP I PRJIT'TE TRADE IN FANCY FRESH EGGS.}

l'erhaps I can do no better than to give vou a chapter wut of my own experience. For several years I lived in a small. country village within an hour's drive of a Massachusetts city of 40,000 inhabitants. The only outlet for $131 \mathrm{y}$ eggs was the city grocer who sent a team once a week to take orders and deliver goods. I had to take just what he would give me. While he was a square man, he was not in business for his health, and made a good profit off the eggs I sold him. It was necessary for me to go to the city once a week on business, and so I decided to take some eggs along. I well remember the morning 1 started out. It was a beautiful summer day, and I took along with me 20 dozen large brown eggs in a new covered basket, thinking that I would have no difficulty in disposing of them. The first place where I called was a drug store on the corner which made a specialty of summer drinks and used a large number of eggs every week. I was told here that they were supplied regularly with all the eggs they needed and could not use mine. I thanked them. bade them a pleasant "good morning," and started out again. It the next drug store they looked at my eggs, but told me they were well supplied that morning, and then asked me if I meant to call every week. I told them I did. I sat down before the soda fountain, ordered a milk-shake and chatted pleasantly with the proprietor while I imbibed the refreshing drink. In the course of the forenonn I risited a number of drug stores and restaurants. but could not find a customer. But in each case I kept smiling and perfectly polite and told them I would call again. I finally succeeded in disposing of my eggs to a grocer for about what I would have got for them at the door. 
But I was not discouraged; I was learning; I knew it would take time to make an impression. Konne was not built in a day.

The next week, the same day of the week, I went to the city again, and had practically the same experience. I did not sell an egg for more than the market price. The third week, the same day, I sold a few dozen to a druggist. By this time the druggists and restaurant keepers were coming to know me, and to find out that they could depend upon my coming to the city every week with a supply of eggs. The fourth week I sold out. After that I had no trouble. I began to take on private custonners from anong those who happened tw be in the drug stores when I delivered my eggs, or among those who patronized the soda fountains and found that when the clerk broke an egg with my stamp on it there was no chick inside. In two months I had all the customers I could supply, who were willing to pay me the highest market price for my eggs, which averaged about 10 cents a dozen more than the grocer would pay at the door.

I attribute my success in picking up customers in a city where I was practically unknown to four things: 1. I had a gurd article. The eggs were fresh and clean and the man who hought a trial dozen to-day would want more the next time I saw him. 2. My wares were presented in an attractive way. They were always carried in a clean covered basket and looked good when I showed them. 3. I kept smiling and pleasant whether a man bought of me or not. I was not easily rebuffed. 4. Regularity in delivery. I went every week, the same day. The druggists and others soon found they could depend on me, and I built up a gilt-edge trade that stood br me and alvertised me to other custumers.

\section{SELIING THE FOIIISS.}

The poultryman has fowls to sell as well as eggs, and if he sells them right he will add materially to his profits. Perhaps I can do no better than to go and tell how I prepared and soid my fowls when I was selling eggs. I did not hunt up private customers. This can be clone, but it takes time, and time is. money. So I deliberately decided to sacrifice one profit and sell to the retail meat dealer, dressing the birds myself. I chose for my objective dealers that had a good class of trade and who would appreciate a gilt-edge article.

Once a week I would go through my pens at night and pick the fowls that I thought ought to be sent to market, using 
the methods of selection described in Chapter VI. These fowls were shut up in a crate and not fed through the day, but were given all the water they would drink. At night I gave them a ration of cornmeal and clear sand, mixed up with skim milk or hot water, and allowed them to eat all they would of the mixture. The next morning when I was ready to kill them, their crops were empty, but their intestines were full, and they had not shrunk in weight as is the case with fowls that are shipped to a commission merchant in the city. The Massachusetts law requires fowls to be sold undrawn. with heads on, and by the nethod of feeding which I have described the shrinkage in weight is reduced to a minimum.

The method of killing was as follows: The fowl was suspencled by its legs by a double cord attached to the floor timhers overhead, and looped at the lower end, at a height which brought the head of the fowl a little below the waist line of the operator. The back of the head was then grasped in the left hand, and held so that it lay in the palm of the left hand, at a convenient height for making the incision. With a double-edged pointed knife, made for the purpose, I made a deep cut about at the point where the head and neck join, cutting across and cutting clear down to the bone. Then as I withdrew the knife I turned the sharp point up and against the roof of the mouth and thrust it into the brain, turning it half around. This is supposed to paralyze the brain and render the bird unconscious. Where the cut across the throat is made aright, a spurt of dark blood follows the withdrawal of the knife and for about a minute the bird bleeds profusely. Then she gathers up her strength for one final convulsive struggle, which, however, is soon over. The struggle seems to unlock or unfix the feathers, and plucking is now comparatively easy. In 15 minutes at the longest the bird ought to be divested of all her feathers.

I would say in passing that in plucking broilers or squalss you are less likely to tear the skin if you sit down and hold the bird in your lap. An old burlap bag will protect the cothes while you are at work upon the birds.

After the bird is denuded of its feathers it should be placed in a tub of cold water and allowed to remain there until the animal heat is withdrawn from the body. Then the lower juint of each wing should be locked across the upper, a noose should be placed around the legs and the carcass bung in a cool place to drip. 
I found it advisable to take the fowls to market on the afternoon of the day they were killed, and tried to make them look as attractive as possible. A piece of clean brown paper was spread upon the bottom of a new market basket and the fowls laid upon that. When the basket was full a clean towel was used to corer the carcasses, so that no dust could get at them. My aim was to make the birds look as attractive and appetizing as possible.

\section{HOIV TO SCALD A FOIVL.}

Where fowls are sold in the local market or shipped to a commission merchant (unless sold alive), they should always be dry picked, but where sold to private customers time will be sared by scalding before plucking. There is a right and a wrong way to do this. In the water in which the fowls are to be scalded put a piece of rosin about as big as an English walnut. The rosin toughens the outer skin and keeps it from breaking or peeling. The water should be just below the boiling point. Take the head of the fowl in the left hand and the legs in the right and dip the carcass in the water, back downward, withdrawing it immediately; then dip it in again, breast downward, and take it out as soon as you can. Now take the carcass and roll a burlap bag around it, letting it remain a few minutes; then unroll the burlap and begin to pick. After the feathers are removed put in cold water and proceed as described in the preceding section.

\section{FINDING A WIDER MARKE'T.}

What about the man who has no market at his door or whose local market is exceedingly linited? In this case he must go abroad for an outlet for his products. He must make up his mind at the ontset that he will have to sacrifice some of the profits, 1)ut this need not discourage him, for, as we have seen in the case of Mr. Dunlap, it is possible to do business at long range and still have a balance on the right side of the ledger.

It is always easier to do business by personal interview than by correspondence, and so I would advise the man who is looking for a city market to devote a few days to looking up customers. It is not always the big city that is the best objective, for the big city draws supplies from a vast territory. For instance, Boston gets eggs from northern New England. from Cape Cod, from the Maritime Provinces and from the West. New York draws her supplies from hundreds of miles 
around. Sometimes a small city situated between two big cities will pay more for eggs and poultry products than either metropolis; for the small city draws from a narrower territory and her supplies are liable to be diverted to the great cities on either side.

Druggists are good customers for fancy eggs and will often sign a yearly contract. The soda fountain trade grows in magnitude each year, and egg drinks are increasingly popular. There are grocery stores catering to a high class of trade which are always anxious to make connections with a poultryman who can be depended on to ship them eggs every week in the year. Clubs, hotels and high-grade restaurants should be approached. There are men in cities who have a private egg route, and these men are on the lookout for producers who can supply them with a first-class article. Perhaps an arrangement can be made with the janitor of a church to handle your eggs as a side line to his regular work. These men have a large acquaintance with families and often would be glad to add to their income by handling your eggs on commission.

In visiting a city to solicit custom, time your trip so that you will approach the prospective customer at a season when the demand is brisk and the supply limited. The proffer of a case of strictly fresh eggs a week the year around is a much more attractive proposition to a city grocer in November than it is in March; and many a man will sign a contract then that will obligate him to take eggs in summer who would not sign it at any other time.

\section{THE COMMISSION MERCHAN'T.}

The commission merchant fills a place in our modern commercial life. It is his business to stand between producer and consumer and find a market for the one and a supply of commodities for the uther. I do not advise shipping to a commission merchant except ás a last resort (for you sacrifice too many profits), but all of us find it necessary to fall back on him at times.

The same advice I gave about finding city customers applies to commission merchants. Spend a day or two in the city once in a while in getting acquainted. Look them up at the bank where they do business. After you begin to ship go to see the merchants once in a while, to let them know you are on the earth. Use them well and you will find that they will use you well in return. 
The commission merchant will send you from time to time a bulletin describing the condition of the city markets. $\mathrm{He}$ will also send you every now and then a postal card with prices marked on it. Ship your goods when he tells you and ship them in the way he tells you. Pack them in an attractive mamer. The commission merchant is anxious to get in touch with the men who have the goods and know how to deliver them, and if you stick to him and use him well you will find that he will do you favors in return, such as notifying you when you can sell to the best advantage and when to withhold shipments from the market.

\section{THE JENISH TRADE.}

The Jewish element in our population yearly increases in numbers and importance. New York is the largest Jewish city in the world, and Boston. Philadelphia, Baltimore. Chicago, St. Lonis, Denver, San Francisco and other great cities have important Jewish colonies. The Jews are good livers and are among the poultryman's best customers. Their religion forbids them the use of lard, and in their cooking the fat of chickens takes its place. The Jews buy only live fowls. as a fowl is not ceremonially clean unless killed by a rablui. The Jewish ecclesiastical year has numerous festivals, and at these festivals an immense amount of poultry is eaten. Ship about a week heforehand for the best prices. The Jewish ecclesiastical year is lunar and not solar like our own: that is, time is reckoned by the moon and not by the sun. Accordingly, the an11ual feasts do not always fall on the same date. The World Almanac, which may be ordered through any newsdealer and retails for 25 cents, will give yon the arrangement for each current year, and should be in the hands of every shipper.

\section{TTV BY-PRODUCTS.}

There are two by-products which are usually wasted, but which if saved and sold would add something to the poultryman's income. The first of these is the feathers. There are men who will buy feathers, if you only know where to find them. Sometimes they advertise in poultry papers; sometimes you have to hunt them up. Pure white hen's feathers are worth about 20 cents a pound; pure white duck feathers, 40 cents; geese feathers range much higher. Colored feathers from the wings and tails are in demand by milliners and bring good prices. 
The other by-product is the manure, of which a large amount is made in the course of the year. I have known a poultryman to take the manure out and dump it in piles on the ground to go to waste. If you do not need it on your own land you can easily find a customer. Ponltry manure reasonably free from dirt and sprinkled lightly with land plaster to retain the ammonia is worth at least a dollar a barrel.

\section{WAYSIDE ADVERTISING.}

Often men range the world over for what they could find at home. No doubt people pass our place every day who want to buy what we have to sell, but we miss their trade because they do not know that we have what they want. There are great possibilities in wayside advertising. On my way to the city I pass a place that always attracts my attention: a very pretty little house with perhaps an acre of land attached. It is a good sized city lot, nothing more. It is owned and occupied, I understood, by a widow with three children. What interests me is the system with which this acre farm is managed. Every square foot is utilized, and every square foot is made to pay. The owner has had a number of neat signs painted, and whenever I go by one of these is out, calling attention to something she has to sell. "Eggs for Hatching" greets my eyes in the spring. Later comes "Strawberries," then "Raspberries" or "Flowers." And in the fall there is a board with the legend "Honey for Sale." I understand that this woman makes fabulous profits out of her acre farm. Cinstomers call at the door and pay big prices for all she has to sell. Her success suggests the possibilities of wayside advertising. Every reader of this book who lives on the main road and has anything to sell should have a number of neat signs painted with the name of some commodity on each, to post by the wayside to be read by passers by. The best market in the world is often at our very doors. I know a man who lives in a country town who had potatoes to sell. He had a sign printed, "Potatoes for Sale," and stuck up where everybody who drove by conld see. As a consequence, he sold all he had for one dollar a bushel, the same price his neighbors received for theirs in the city, six miles away. If a hundred people pass your door every twenty-four hours, the chances are that some of them will be interested in what you have to sell. 


\section{CHAPTER VIII.}

\section{Laying Down Eggs.}

There is no article in daily use that I know anything about the price of which varies with such astronomical regularity as does that of eggs. Their movement up and deww is as periodic as the rise and fall of the tides or the oscillations of the pendulum. Generally the period of lowest prices begins in March and continues well inte May. 'This is the natural lireeding season of fowls, and eggs are pruduced in greatest abundance. By the first of June eggs begin to take an upward turn, and advance slowly until September. In September many of the older fowls begin to moult. and cease production altugether. From this point the rise is rapid, reaching the maximum at Thanksgiving. then the price drops a little, but soon recovers itself and continues high until well into January, when it begins to break, dropping rapidly in February and March as the spring floud of eggs comes into the market. This is the general trend of things year after year. but is subject to slight annual variations, for some seasons are more favorable to egg production than others: and in any year a sudden warm or cold ware may cause a break or rise in prices.

Now it follows from what has been said that it would be wf great advantage to producer and consuner alike if some simple, practical nethods of preserving eggs were generally known and adopted. It would be of great advantage to the producer because it would serve as a balance weight and prevent eggs from dropping so low that it is unprofitable to produce them. Statistics show that the average hen does not produce over 120 eggs a year, and nearly half of these are laid in March, April and May. If the owner of the len cuild nhtain, say, a cent apiece more for these eggs it would mean a great addition to his annual profits.

If every poultry keeper in the United States would lay down his family supply of eggs for the year in March it would take at least 250,000,000 dozens of eggs out of the market at a time when eggs are lowest, and the price of eggs would never drop below 25 cents a dozen. For ly April millions of 
dozens morc are required for incubation, and this absorbs the surplus to a considerable extent.

And it would be a great advantage to the consumer if he or she would lay down the year's supply in the spring. There is no article of diet more nutritious and healthful than eggs. They are in themselves a perfect food, and are easily prepared. In England eggs appear on the breakfast table of the better classes every day in the year. and it would be better for the people of this country if they ate more eggs and less meat. And yet at certain seasons of the year the price of fresh eggs is practically prohibitive. Who can afford to have fresh eggs for breakfast when they are 45 or 50 cents a dozen? Only the wealthiest and nust extravagant. Tlow much it would mean to the health and economics of every family if they knew how to lay down the family supply of eggs in the spring, when eggs are at their best and lowest in price!

\section{COLI) STOR.GE.}

Cold storage is the process of preserving eggs, meats, fruits, etc., by keeping them in a temperature so low that decay is impossible. Decay is produced by bacteria, microscopic vegetable organisms, which multiply with marvelous rapidity, or by stimulation of the germ of life already within the egg. Chemical changes follow, and the result is fermentation and decomposition. Like all living things, these bacteria require warmth for development. When the temperature is kept near the freezing point their ravages are held in check, and the substance to be preserved does not change in composition.

Storage plants are now erected in all our larger cities and are under government supervision. In the largest of them Luited States inspectors are constantly on duty to see that they are maintained nnder sanitary conditions. 'The articles to be refrigerated are stored in large chambers or compartments, where the temperature is reduced by the constant circulation w ammonia through pipes or by means of ice.

Thumsands of cases of eggs (each case containing 30 dozens) are placed in these storage plants every season, to be liberated as they are needed. These eggs are largely Western eggs, few kastern eggs being available for the purpose, and come from farms and ranches. They are bought when eggs are lowest and average two weeks old when put in storage. "The egg chamber is supposed to be kept at a temperature of 32 alegrees, cold cnough to freeze cracked eggs, but not cold 
enough to freeze whole ones. They are taken out in practically the same condition they are put in. Indeed, eggs have been kept in cold storage for three years and when taken out could not be distinguished from eggs that had been there only a short time. Defore being placed on the market each egg is "candled," or expused to the rays of an electric light, which reveals its condition. If the egg is clear it is passed; if cloudy, it is thrown out and sold to morocco dressers to be used in tanning their leather. Cracked eggs are placed in a class $h y$ themselves and sold to bakers.

Culd storage plants might be used by poultrymen who live in the neighborhood of cities to sture their surplus product. The price charged for storage is low. At the large plant at which I obtained material for this chapter the rate of storage is only 10 cents a case a month. Is each case contains 30 dozens, it would cost only two cents a dozen to hold eggs six months, when they conld be sold at a large increase. Storage eggs generally sell for about two-thirds the price of the fresh article. But these eggs, as I have said, will average two weeks old when put into storage, and many of them are very inferior specimens. There is no reasum why selected aggs from the farm, laid down when perfectly fresh, should not sell at retail arwund the price of new-laid eggs, for they equal new-laid eggs in many particulars. I was surprised in going through a large local plant to learn that poultrymen did not avail themselves of the opportunity that lay at their very doors. If it pays the cold sturage men to buy eggs in the IVest, with the inevitable breakage in transportation, carry them six months and then sell them for twr-thirds the price of fresh eggs, it would certainly pay the poultryman to put his own eggs in storage; for there would be 110 breakage. no express, no shrinkage in "candling." and the eggs would be sure to be fresh when laid down, and not two weeks or more old.

Where there is no culd storage plants at hand the poultryman can construct one at a moderate cost. In this case he would cool his plant not with chemicals, but with ire. A small building may be constructed for the purpose, or a room can sometimes be fitted up in the shed or stable.

\section{LIME AND SALT SOLU'TION.}

Decay being caused by bacteria or germs, it follows that if these can be combatted or excluded decay will be arrested. This may be done in five ways: 1. By keeping the eggs at 
such a temperature that the germs remain dormant, or cold storage. 2. by immersing the eggs in a solution which will (w) the shell and prevent the entrance of air, the great germ carrier. 3. Ty crating the shell with some substance that will make it impervious. 4. By destroying the germs by means of the $\mathrm{X}$ ray. 5. By a combination of one or more of these processes.

In the past many have attempted to preserve eggs by packing them in salt, wood ashes, plaster, or even in oats; and when the period was short have met with comparatively good success. Experiments, however, have shown that these substances are not to be depended on when it is desirable to keep eggs in good condition for some months, and more effectual preservatives must be discovered.

Probably where eggs are to be laid down for family use one of the best methods is to use the line and salt solution. It is inexpensive, easily prepared, and will surely do the work. Eggs laid down by this method are liable to have a slightly limy taste. which interferes with their being placed on the market. But for home use they are excellent.

The formula appears in several forms, but the best is the one which follows, which, so far as I know, has never before been made public:

Mix three pounds of quick lime in three gallons of water that has been boiled and cooled. Slake the lime in part of the water before adding all. Stir well; then add one-lialf pound of common salt. Ifter stirring a ferv times let stand for sereral hours to settle. Separate the clear liquid for use, and in this dissolve one-fourth ounce of boracic acid.

L.ess lime will suffice, if of good grade, but the formula calls for enough to insure a saturated solution. Solutions containing more salt sometimes serve well, but with an excess of salt the egg yolk is often found thickened. Saturated solutions of lime alone have been used successfully.

Eggs are kept immersed in this liquid, which should cover them continuously to the depth of two inches or more. Glazed earthenware, glass, or clean wooden receptacles, are used, and should be stored in a conl place, as on a cellar floor, until the eggs are wanted. Eggs just taken from the liquid should not be subjected to a sudden rise in temperature.

The amount of solution made by this formula will be found sufficient to preserve 12 dozens of eggs; if more eggs are to be preserved the proportions should be increased. 
For successful preservation by any method eggs must be absolutely fresh with clean and perfect shells.

Note.-In any of the solutions given in this book allow one (puart of the solution to each dozen eggs. The reader can thus determine at once what quantity to prepare:

\section{IVATER GLASS.}

As we have seen, decay originates from one of two sources: 1. The stinulation of the germ of life within the egg. 2. The introduction of bacteria from without. Either of these sources will produce chemical changes that will destroy the freshness of the egg. Exposing the egg for a few days to a high temperature will start incubation if the germ of life is present; and exposing the egg to the outside air for a longer period will cause decay by the introduction of germs from without, even if there is no germ of life within.

Cold storage is the perfect method of preservation, for the low temperature stops the development of germs both within and without. As in the world without us all vegetable growth is checked by the cold of winter, so artificial cold checks the growth of bacteria, which are minute vegetable organisms, and decay is prevented. But, as we have seen. cold storage is not practicable in all cases, and so other methods must be substituted.

Following out the principle we have discovered-that all decay comes from the stimulation of the germ within the egg or the introduction of germs from without-we can easily see that if we can keep the egg from the air, the great carrier of germs, and also keep it at a low temperature. we shall greatly retard if not altogether prevent those chemical changes that we call decomposition.

In the section before this I have given the formula for a salt and lime solution that has proved very effective. In this section I shall outline a method that is rapidly advancing in favor and is probably destined in time to supersede the others. I refer to the use of soditum silicate, or water glass, as it is commonly called. Water glass is cleanly, convenient and sure; and where it can be ohtained at a reasonalole price should be given the preference.

Where it Can Be Obtained.-The merits of water glass as an egg preservative are becoming known and there are many inquiries for it at the local druggist's. But the price charged is often prohibitive. I have known a woman to pay 30 cents 
a pint for the article. One gallon of water glass in the 10 per cent solution (one part water glass to nine parts water) will preserve 40 dozen eggs; and at 30 cents a pint it would cost six cents a dozen to lay down eggs-a price that is altogether excessive. Unless it can be procured at a much less cost than this its use is out of the question.

Where water glass is bought in gallon lots (and no one should buy less than this) it can be obtained of wholesale druggists for 50 cents a gallon. The Eastern Drug Company, 8-20 liulton street, Boston, Mass., quotes me the following prices: In gallon lots, 50 cents a gallon, with 20 cents extra for can, which is returnable. In five-gallon lots, 35 cents a gallon, and 75 cents for can; can returnable. In barrels of 600 pounds, $1 / 2$ cents a pound, or $16 \mathrm{~T} / 2$ cents a gallon. John Shaw \& Co., 40 India IVharf, Boston, manufacturing chemists, put up water glass in gallon cans, especially for egg preservation, for 50 cents a gallon; no charge for can. I have no doubt that in every large city water glass may be procured of wholesale druggists at a reasonable figure.

The best way to buy the article to advantage would be for a little group of neighbors to club together and purchase five gallons at a time, or even a barrel. In dividing it, remember that it is sold by weight rather than by measure-11 pounds constituting a gallon.

How to Use It.-The formula most generally used calls for a ten per cent solution-that is, one part water glass to nine parts water. In order to secure a perfect fusion the water whould be at the boiling point when added to the water glass, and the solution should be stirred for several minutes with a stick. Meanwhile the eggs should be got in readiness. For containers use clean wooden barrels, or firkins, stone crocks, galvanized iron tubs, or in fact, almost any receptacle that is convenient. Put in the eggs, and after it becomes cold pour on the solution. The eggs should be well covered with the liquid, and the container shonld be set away in a conl, dark place-the cellar, if possible.

While a ten per cent solution is generally recommended, yet is is probable that a much weaker solution will answer every purpose. Experiments conducted at the Rhode Island station showed that a five per cent solution-one part water glass to 19 parts water-will keep eggs perfectly. Owing to evaporation the solution is continually growing stronger, and its preservative qualities enhanced. 
Chemical changes will take place in the solution after a little period. It will begin to coagulate and whiten, until after a while it resembles whitewash in appearance. Then a jelly-like precipitate will form, and the eggs near the top will become coated. The reader need not be alarmed at these chemical changes, for they do not interfere with the preservative qualities of the solution. The weaker the solution the less pronounced the chemical changes, and the smaller the amount of precipitate. A ten per cent solution will keep eggs perfectly, and is to be recommended for the beginner. After a few experiments he acquires confidence, and will not hesitate to use a weaker solution. The writer uses a $62 / 3$ per cent solution-one part water glass and 14 parts water.

When to Lay Down Eggs.- There one keeps his own hens and can obtain a supply of eggs at any time, the writer would recommend that eags be laid down in March. The spring weather always stinulates egg production, and so many eggs are put on the market, the price often drops to a point where it actually does not pay the cost of producing them. The more eggs taken wut of the market at this time of year the less likely to be a slump in prices. Where it is necessary to purchase eggs to lay down they may be buught at any time in March, April and May, the months of low prices.

How to Tell Fresh Eggs.-Eggs should be perfectly fresh when put into solution, and it is not always easy to get fresh eggs where one has to go into the market and buy. The solution itself affords a good test of the freshness of the egg that is put into it. If the egg sinks to the bottom it is fresh and will keep well, but if it floats it is stale. The higher it floats in the water the longer it has been laid. The reason for this is that the air cell in the egg has a tendency to increase in size, owing to evaporation through the pores of the shell; and the older the egg the larger the air cell and the higher it floats.

Marketing Preserved Eggs.-Where eggs are laid down to be sold again much greater care must be exercised than where they are laid down for family use. In the first place, the number of eggs is far larger, and in case of a loss it will be more severe than where only the family supply is involved. And in the second place, the eggs must have a fresh, bright appearance. Where eggs are to be eaten at home the ap- 
pearance of the shells is of minor importance so long as the eggs are fresh. but where they are to be put on the market one cannot be too particular.

Make the solution as I have described: one part water glass and 10 to 15 parts pure water. Lay down your eggs erery day, and as soon as they are put in the tub cover them with the solution. A tub will hold from 40 to 50 dozen eggs, according to its size and according to the size of the eggs; and I have found the tub numbered "two" most suitable for my purpose.

Do not put into the tub as many eggs as it will hold, but fill it so that the eggs can be covered to the depth of two or three inches with the solution. There will be some evaporation during the summer months, and if the eggs are too near the surface some of them will be left high and dry before the summer ends, and you will have rotten eggs for your pains when you come to sell them.

Each tub should have marked on it with chalk the date on which the eggs were laid down. Thus, eggs laid down in March should have "March" chalked on the tub, and those laid down in April should be distinguished in a similar way. In selling the eggs you will want to begin with the oldest and put them on the market first.

The board that covers the tub should be lifted from time to time, and the eggs inspected to see that everything is all right. In case of doubt it is well to take out a few eggs from the suspected tub and break then. But if the eggs were fresh when laid down and the solution is of the right consistency, there is really very little danger.

In laying down eggs for market be sure to select those with the whitest shells. The water glass seems to enter into chemical combination with brown-shelled eggs, turning them a pinkish hue. But it has no appreciable effect upon lightshelled eggs. Indeed, it is practically impossible to tell those which have been in the solution from those which have not, when they are ready for market.

When the time comes to sell the eggs you will begin with those that were laid down first. As I have explained, the water glass will probably have coagulated, and the eggs will be covered with a jelly-like precipitate. Remove as much of this as possible when you take out the eggs, splashing each egg around in the water. Put the eggs in a tub similar to the one they were taken from. After the tub is filled pour 
on suft. cold water and let stand 24 hours. Then take the eggs wut of this and put in a basket, washing each egg before it is taken ont and rubbing off all traces of the water glass with the fingers. Ifter the eggs are dry they should be gone over again. They will have a rungh appearance, and look as if they had been in an old flour barrel, or been sprinkled with chalk. A hrisk rubbing with a woolen cloth or old towel will greatly improve their appearance, and make white-shelled eggs look at good as new. If you care to go to the trouble. a final tnuch with a cloth wet in strong vinegar, and then wrung nearly dry, will make them look very nice. Water glass is an alkali and is neutralized by the acid in the vinegar.

And now about marketing these eggs. They are not strictly fresh eggs, and must not be sold as such: and, on the other hand, they are much better than the average coldstorage eggs. I good way to sell them is to show them to your customers, tell them they are laid down by a special process, and that you will sell then for five cents a dozen less than strictly fresh eggs, guaranteeing to replace every one that is not satisfactory with a fresh egg. You will have no trouble in disposing of your stock for double what you could have got for them in the spring. 


\section{CHAPTER IX.}

\section{Becoming a Fancier.}

It will doubtiess be a surprise to many who read this chapter to learn that for the average poultryman there is more money in utility than in fancy fowls. A little reflection will show why this is so. The fancy business requires the personal touch. I man who is keeping fowls for meat and egegs can delegate much of the work to others, and can increase his plant indefinitely. But the fancier must know his bircls as individuals, or else employ a high-priced superintendent who does. He must know how to mate and handle for best results, and even then not one bird in ten will be likely to be a prize winner. He must pay out more for foundation stuck, and if he wishes to introduce new blood must often spend hundreds of dollars for what he wants. He must take his hirds to the shows, and the car fare, express charges, entry fees, loss of his own time, etc., will make a lig hole in his profits. Then he must advertise, and advertise generously, and advertising runs away with a lot of money. So it will be seen that the breeder of fine birds must get good prices for what he has to sell if his books are to show a balance on the right side.

\section{THE APPEAI, OF THE FANCY.}

Still there are many to whom fancy puttry keeping makes a strong appeal. The Creator of the universe has implanted in man a love for the beautiful, and there are few objects in nature more beautiful than a fine specimen of one of the standard varieties at its best. There is an excitement in the attempt to produce a bird that will score high in the $90 \%$, like the excitement of the chase. In the show room there is a battle royal that appeals to a man's fighting blood. The breeder is matched against other breeders of his favorite variety, and victory over them is sweet. The silver cup and the blue ribbon that he takes home to show his friends have a value that money cannot represent. But there is good money, too, in fancy poultry. If a man can produce a specimen of any one of the popular varieties that will win the 
blue at one of the big shows, he can name his own price. Five hundred, one thousand and even fifteen hundred dollars have been paid for a winning male. Then it does not take much land or many buildings for a man to carry on quite a business in fancy poultry, and world-beaters may be raised in a back yard. All these things conspire to recruit the ranks of the fanciers with a stream of new nnen who are after fame and fortune in the poultry business.

\section{BECOMING A FANCIER-THE START.}

Lnless a man buys his birds and shows as his own what other men have produced, the one who aspires to be a fancier must make up his mind to a long, slow, up-hill climb. But at the summit of the hill there waves a blue banner with the word "First" upon it in golden letters, and there approaches to meet him one of Uncle Sam's servants in the grey uniform of a letter carrier with a big bundle of letters, each containing a check for sittings of eggs and shipments of birds.

The first thing a man should do who aspires to be a fancier is to purchase a copy of the American Standard of l'erfection, and the second thing is to decide upon the variety he will keep. The Standard of Ferfection is the official publication of the American Poultry Issociation, and contains a complete description of all recognized varieties of fowls. It supplies the breeder with the ideal that he is to try to make real in his yards. As a man turns over the pages of the standard and sees the beatutiful hirds pictured there, he is quite apt to hecome bewildered and to wonder how he can ever make a choice. But here is where the fancier has an advantage: the field is much wider for lim than for the man who keeps utility fowls. In the utility field there are not more than six or eight varieties that are noney makers, while in the realn of showdon a man can make money on any one. of half a hundred kinds. If a man breeds good birds and advertises them faithfully, he can find customers no matter what variety he selects. Then in a non-popular variety there. is not so much competition in the show room, and a blue: ribbon comes one's way much sooner than is the case where. competition is fierce. Still I wonld advise a man to select a rariety that is reasonably popular, or he will be disappointed in sales. If he is shrewd or lucky enough to hit upon a breed that is about to have a boom and gets into it before the crowd, his fortune is made. Let me illustrate. The Jight 
Brahmas are grand birds-there is something majestic and stately about them. They are handsome. They have many friends. Still, I would not advise a man to go into Light Brahmas. They have had their day. But the Columbian Wyandotte, which is a new variety, with Light Brahma markings but Wyandotte size and shape, would seem destined to have a great run; for they appeal to those who admire the Light Brahma markings and to those who admire the many good qualities of the Wyandottes. If I were starting out I should not hesitate to try them.

\section{THE FOUNDATION STOCK.}

Perhaps ás good a way as any to get a start is to purchase a pen of birds of the variety one has decided upon of some reputable breeder in the fall. Ask him to mate them up for you for the best results. You can generally buy old birds for considerably less than you can young ones, and where you are not after eggs for market but for incubation, old birds are as good or better than young ones. You will devote the winter to getting acquainted with your birds. (I assume that you have kept fowls before and understand their care and management. If you do not, it will hardly pay you to start out with high priced specimens at first.) In the spring you will get out all the chicks you can take care of, and in the fall should have several pens of likely pullets. Mate your cock bird with the best of these, and send off to the man of whom you bought your foundation stock for more males.

\section{SHOW YOUR BIRDS.}

One who aspires to become a full-fledged fancier must show his birds. 'There is nothing that will help out sales like a good show record. There is no place in. which a man can learn so much in a short time as in the show room. It is a liberal education to see the judges work; and the score card that one finds attached to his coop is of inestimable value: it reveals to a breeder as by a flash of light where his birds are strong and where they need to be built up.

PREPARING BIRDS FOR SHOWV.

The Standard of Perfection should have a chapter on the preparation of birds for the show room: it would be worth the price of the book to a beginner. I do not claim to be an expert, but perhaps I can give a few hints that may be of assistance. 
After the owner selects the birds that seem to him the best, he should examine them carefully to see that there are no disqualifications-nothing that will throw the bird out of the competition. The bird should be healthy, vigorous, free from vermin, and as near the standard weight as possible. Of course the prospective exhibitor has handled his birds more or less and treated them so well that they are reasonably free from shyness. There is nothing that looks worse than to see a bird in the exhibition coop dashing its head against the slats in its vain efforts to escape, or crouching in the corner as if half frightened to death. White birds should be washed, and I am inclined to think that a good washing will not harm birds of other colors. The process is very simple. Three tulbs half full of water should be set side by side, of a temperature of about 95 degrees. The birds should be stood in tub number one and well soaped with Ivory or some good white soap, taking care to rub the soap the way the web of the feathers runs. After the bird has been well soaped, remove it to tub number two, and rinse the lather out of the plumage. The bird should then be removed to the third tub and given a final rinse. If the bird is a white one, a little bluing should be added to the last water. Take the bird from the water and stand it on a table or box, and wipe it as dry as possible with towels. If you have a furnace in your house, and your wife will let you do so, place the sawhorse over the register and let the bird stand on the round of the sawhorse for a little while. He will be so tamed by this time that he will not try to get away. If you have no convenient register, place the bird in a large slatted box, well littered with straw, and let him remain in the box in a warm room until thoroughly dry. Before shipping the bird to the show feed him well, give him a little whiskey and water or a onegrain quinine pill, and rub his comb and wattles with a piece of flannel which has been saturated with alcohol. Dig out the dirt from under the scales on the legs with a toothpick, and rub the legs briskly with a piece of chamois skin.

\section{ADVERTISING.}

For everything a man has to sell there is another man somewhere who stands ready to buy, and there is a man somewhere waiting to buy stock and eggs of you. How may you find him? I can tell you in one word-Advertise.

I used to think that something could be done through the 
local paper to sell stock and eggs, but an experiment has rather shaken my confidence. The fact is, not one reader in a hundred of the local paper is willing to pay a living price for stock and eggs-he doesn't know their worth. If you can afford to sell eggs for hatching for from 50 cents to a dollar a sitting, and cockerels for one or two dollars each, you can sell some by advertising in the local press; but if you want a living price you must look elsewhere. The poultry press is the place for a poultryman to advertise. Time and time again have I had men come to me to borrow a poultry paper to find out where they could get stock or eggs of a certain variety.

Fortunately there are a number of grand poultry papers in this country and Canada, and any one who has anything to sell can easily find a good medium. How shall a man decide what papers to advertise in? There are two rules: 1. Advertise in papers that carry the most advertising. 2. Advertise in papers that themselves advertise.

Advertise in papers that carry the most advertising! "But is not my little ad. in danger of being lost in the mass?" you ask. Not at all. The paper that carries the most advertising does so because it is the best medium. Men advertise in it because they have found it pays. Somebody is going to see and read your advertisement, and send to you for birds.

Advertise in papers that themselves advertise! Why? Because those papers have for their readers those who answer advertisements. The reader with the mail-order habit is the one you want to go after.

"How large an appropriation shall I set aside for advertising?" For a beginner, a good rule is one dollar a year for each bird in your breeding pens. If you have 50 birds your appropriatinn should be $\$ 50$. For $\$ 50$ worth of advertising you ought to be able to sell $\$ 400$ worth of eggs and stock.

As you increase your breeding stock you can decrease the amount you allow for each bird, for a large advertisement pulls proportionately better than a small one.

Some papers have what is called a flat rate-so much an inch, whether for one insertion or twelve. Others have a sliding scale-the rate being less proportionately for a year than for three or six months. Where you advertise with a paper that has a sliding scale you can arrange so as to use the greater part of the space from October to May, and cut down in the summer months. 
Poultry papers generally offer special inducements to beginners and small breeders by running short, classified ads. at a low rate. 'These are called "Breeders' Cards," and I know of no way in which a man can nake his advertising appropriation go so far as by patronizing this department of the paper.

Writing a good advertisement is quite a trick, but like all great things it is simple. The best advertisement tells a story and gives a reason. It is not funny, it is not verbose, it is not sensational, it is not extravagant. It is a plain, striking statement of facts. Write out your story, then strike out every unnecessary clause and word, and let the printer display it to suit his taste. Study the advertisements of successful men in other lines, especially in the magazines, and you will learn much from them.

Besides your advertisement in the paper you will need a neat and attractive circular. The circular will describe your stock more fully than the advertisement. The circular will sare you a rast amount of letter writing, for it will answer nine-tenthis of the questions asked by prospective customers.

Attend to your correspondence promptly, if possible answering a letter the very day it is received. The man who writes you may have written some other fellow at the same time, and if you want his trade you must be prompt.

Encluse a circular in each letter, but do not rely upon the circular to make a sale. Write a few cordial, friendly words, even if every question the man asks is answered in your circtilar. Tersonality is the greatest power in the world, and you can put a good deal of personality in a short letter.

\section{SHIPPING EGGS AND STOCK.}

Eggs for hatching are generally shipped in a basket or box made for the purpose. In cold weather they should be moved only in the middle of the day, and great care should be exercised to prevent freezing.

Where eggs are shipped by the hundred, perhaps as good a way as any is to pack each separate egg in excelsior. Take a small piece of excelsior from the roll and pull the fibres apart, then with your thumb or with a round stick like the end of a broom handle, make an indentation in the mass. Put the egg in the hole and close in the excelsior about it. The egg is now in a ball or nest, protected on every side by 
its resilient carrier. If carefully done the ball may be dropped upon the floor and the egg inside will not break. These balls may be packed in a box like oranges, and will go safely any distance.

In shipping stock, provide light and strong shipping coops. If the bird is to go any distance, a loaf of stale bread soaked in water and placed in the box will be meat and drink for him on his way. Write the party to whom you ship the bird when you send him, enclosing express receipt.

\section{COMPLAINTS.}

Every shipper of eggs and stock is bound to receive more or less complaints. Accidents will happen, and there are customers hard to please. Sometimes you run across a dishonest customer who wants to get more than his money's worth and who sends in a complaint that the eggs were broken when they reached him or failed to hatch. You can generally tell from the tone of a letter whether the writer is sincere or not, for an honest letter has an honest ring.

When a complaint comes in that is unreasonable, it should be, met courteously and kindly, but firmly. The customer should be shown, if possible, the untenability of his position. When a complaint that is reasonable comes in an attempt should be made for a satisfactory adjustment. It is the practice among poultrymen, I believe, to duplicate the order at half price where less than seven out of the thirteen eggs hatch. Where a customer is dissatisfied with the bird sent, he should be allowed to send him back, paying the express. and his money should be returned to him. While a poultryman needs to make sales he needs to make friends even more, and a good way to secure them is to treat every man according to the teachings of the Golden Rule. 


\section{CHAPTER X.}

\section{The Trap Nest.}

The trap nest is a box or compartment with a spring door which automatically closes and locks behind the hen as she enters to lay her egg and keeps her imprisoned until released by an attendant. The great advantage of the trap nest is identification. It enables the poultryman to pick out the hen that lays the egg. By attaching a leg band to her ankle with a number thereon and keeping record, the poultryman can easily determine the number of eggs a hen lays in a given period.

Ten years ago, when the trap nest was a new thing, it was confidently predicted that it would revolutionize the poultry industry. It seemed self-evident that all one had to do in order to secure a strain of phenomenal layers was to breed from the birds giving the largest egg output. But experience has demonstrated that there is a flaw in this theory somewhere. It does not work. At the Maine Experiment Station. where the trap nest was used faithfully for several years, it was found that there was actually a decrease in egg production, that the phenomenal layers did not reproduce themselves.

There are reasons for this anti-climax, if we can only discover them. It is impossible in any given case to determine how much the egg output is influenced by heredity and how much by enviromment. Take a Light Brahma and keep her under favorable conditions, well housed and well nourished, and she will surpass in egg production a Leghorn that is compelled to dig her living out of the manure pile and left to roost on the branches of an apple tree. The phenomenal layer may exhaust her vitality in excessive egg production so that she is unable to transmit the faculty to her offspring.

The great practical argument against the trap nest is that it takes so much time-time that would better be devoted to caring for the comfort and convenience of the fowls. In order to properly operate trap nests it is necessary to visit the house five times a day; and to remove a hen from the nest and credit her with the egg laid on a sheet of paper takes 
at least one minute. Where 500 fowls are kept there will be times when the operator will be kept busy six hours a day looking after the nests. The poultry business is sufficiently laborions and confining in itself without taking on this extra burden.

From what has been said it might be inferred that the writer is opposed to the trap nest. Not at all. What the writer is opposed to is the extravagant claims that have been made by advocates of the trap nest and especially by those who have plans to sell. The trap nest has its uses. The great value of the trap nest, in my judgment, is not that it enables us to breed from the heaviest layers, but that it prevents us from breeding from the poorest ones. In the same Hock there will be birds that will lay two dozen eggs a year and other birds that will lay two hundred. We want to cull out these weak layers, and the trap nest will help us do it. Then the trap nest may have a great value in pedigree breeding; where a fancier wants to be sure that he breeds from a special fowl.

\section{MAINE EXPERIMENT NEST.}

The Maine Experiment Station, which has given to the ponltry world so many goud things, has the plan of a trap nest which is simple, practical and easily constructed. "The nest is a box-like structure, without front end or cover, 28 inches long, 13 inches wide, and 16 inches deep, inside nueasure. A division board with circular opening $75 / 2$ inches in diameter, is placed across the box 12 inches from the rear end and 15 inches from the front end. Instead of having the partition between the two parts of the nest made with a circular hole, it is possible to have simply a straight board partition extending up 6 inches from the bottom, as shown in Figure 1. The rear section is the nest proper.

"The front portion of the nest has no fixed bottonn. Instead there is a movable bottom or treadle which is hinged at the back end (Figure 1). To this treadle is hinged the door of the nest. 'The treadle is made of $1 / 2$-inch pine stuff, with $1 / 2$-inch hardwood cleats at each end (Figures 2 and 3 ) to hold the screws which fasten the hinges. It is 12 inches wide and 12 T/4 inches long. Across its upper face, just behind the hinges holding the door, is nailed a pine strip 4 inclies wide, beveled on both sides, as shown in Figures 2 and 3. The dnor of the nest is not made solid, but is an 
open frame (Figures 1 and 3 ), to the inner side of which is fastened (with staples) a rectangular piece of $1 / 8$-in. mesh galvanized screening (dimensions 8 by 9 inches). The sides of the door are strips of $3 / 4$-inch beech stuff 12 inches long and $1 \mathrm{r} / 2$ inches wide, halved at the ends to join the top and bottom of the door. The top of the door is a strip of hard wood 13 inches long and $1 \frac{1}{2}$ inches wide, halved in $23 / 4$ inches from

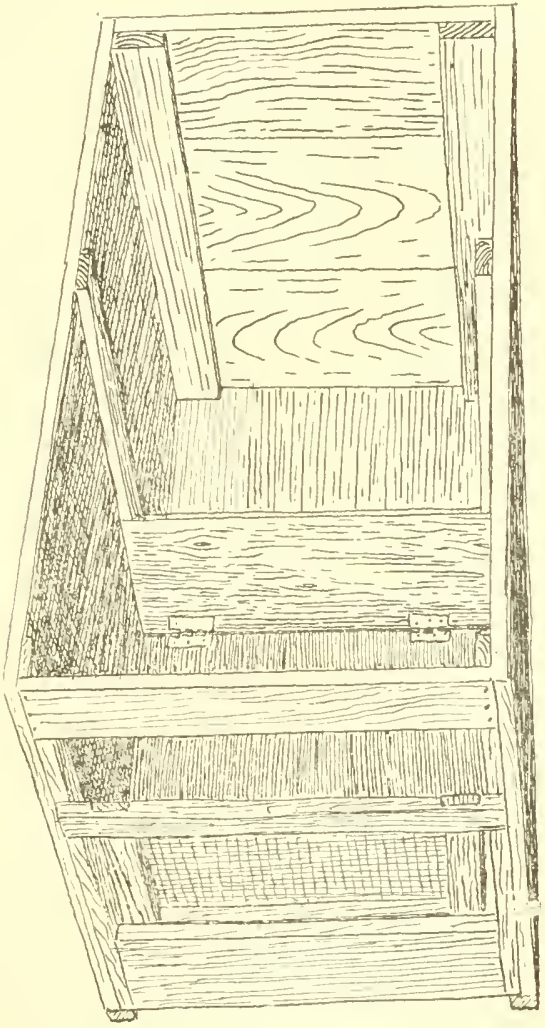

Fig, 1. Trap Nest closed. View from above.

each end. The projecting ends of this top strip serve as stops for the door when it closes (Figure 1). The bottom of the door is a hardwood strip $10 \mathrm{I} / 4$ inches by 4 inches. The side strips are fitted into the ends of this bottom strip in such a way as to project slightly (about $1 / 32$ inch) above the front surface of this strip, for a reason which will be apparent.

"When the nest is open the door extends horizontally in front as shown in Figure 2. In this position the side strips 
of the door rest on a strip of becch $1 \frac{\mathrm{I}}{2} \mathrm{inches}$ wide, beveled on the inner corner, which extends across the front of the nest. This beech strip is nailed to the top of a board 4 inches wide, which forms the front of the nest box proper. To the botton of this is nailed a strip 2 inches wide, into which are set two 4 -inch spikes from which the heads have been cut (compare Figure 2). The treadle rests on these spikes when the nest is closed. The hinges used in fastening the treadle and door are narrow 3-inch galvanized butts with brass pins, made to work very easily. It is necessary to have hinges which will not rust.

"The manner in which the nest operates will be clear from an examination of Figures 2 and 3, which show a sample nest with one side removed to show the inside. A hen about

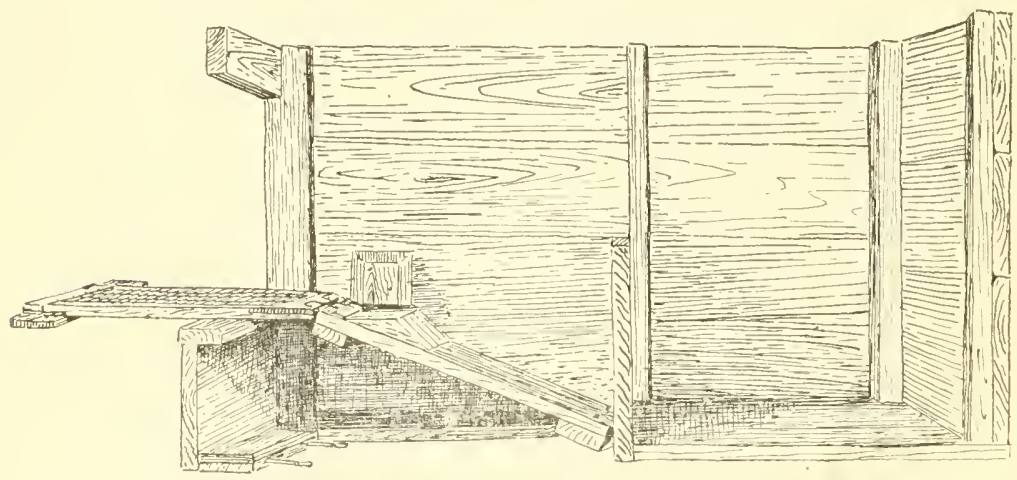

Fig. 2. Trap Nest mpen. One side removed to show method of operation

to lay steps upon the door, and walks in towards the dark back of the nest. When she passes the point where the door is hinged to the treadle, her weight on the treadle causes it to drop. This at the same time pulls the door up behind her, as shown in Figure 3. It is then impossible for the hen to get out of the nest till the attendant lifts the door and treadle and resets it. It will be seen that the nest is extremely simple. It has no locks or triggers to get out of order. Yet by proper balancing of door and treadle it can be so delicately adjusted that a weight of less than half a pound on the treadle will spring the trap. All bearing surfaces are made of beech, because of the well known property of this wood to take on a highly polished surface with wear. The nests in 11se at the Maine Station have the doors of hardwood, in order 
to give greater durability. Where trap nests are constantly in use, flimsy construction is not economical in the long run. For temporary use the nest door could be constructed of soft wood.

"The trap nests are not made with covers, because they are used in tiers and slide in and out like drawers. They can be carried away for cleaning when necessary. Four nests in a pen accommodate 20 hens, by the attendant going through the pens once an hour, or a little oftener, during that part of the day when the hens are busiest. Earlier and later in the day his risits are not so frequent. The hens must all have leg bands in order to identify them; a number of different

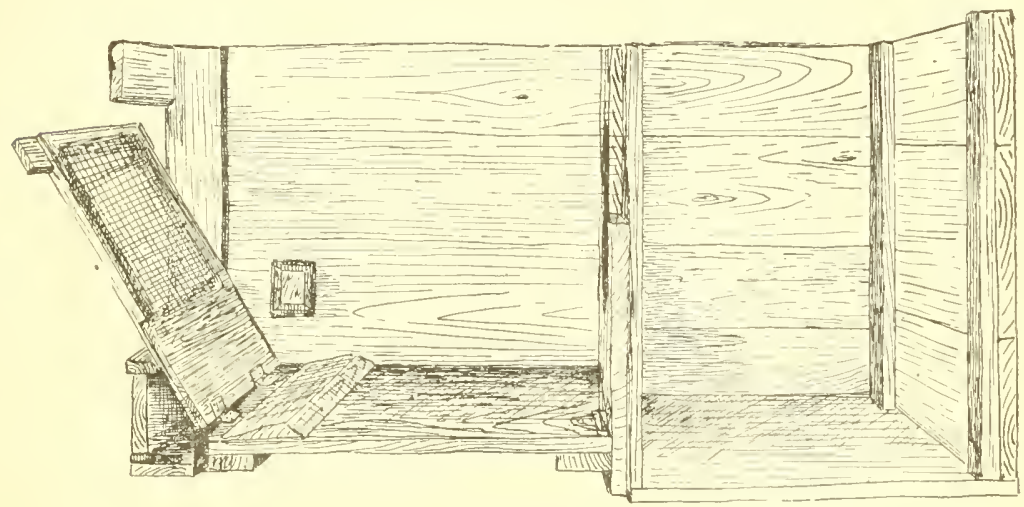

Fig. 3. Trap Nest closed. One side removed to show mathod of operation.

kinds are on the market. The double bux with the nest in the rear is necessary. When a hen has laid an egg and desires to leave the nest, she steps out into the front space and remains there until she is released. With one section only she would be likely to crush her egg by stepping upon it, and thus learn the pernicious habit of egg eating.

"To remove a hen the nest is pulled part way out, and, as it has no cover, she is readily caught; the number on her leg band is noted and the proper entry made on the record sheet. After having been taken off a few times the hens do not object to being handled; most of them remaining quiet, apparently expecting to be picked up."

\section{IN CONCLUSION.}

Capitalize your mistakes.

Don't slip twice on the same banana peel. 
Don't trust anything to a hen's judgment, for she hasn't any. She is sure to do the thing you don't want her to do. The only safe way is to have your fowls where they are completely under your control.

Reat widely, but check and correct what you read by experience and experiment.

The best breed is the one you like best.

Cleanliness is next to egginess.

Keep the hens at work, and the chances of their contracting bad habits will be reduced to a minimum.

A good breeding cockerel should be of good size, with well developer comb and wattles, a bright eye, and with a bright and fearless mien. In other words, he should show his masculinity in every act and look.

Separate the sexes as soon as the cockerels begin to crow.

The time to doctor a sick hen is before she is sick.

Give value received the first time, or you may never have a second time.

Fowls should never be roughly handled, violently chased or badly frightened. Best results can only be obtained when the birds feel at ease and free from the attacks of enemies of all kinds. The keeper. whose fowls fly at his approach, is not a success.

Satan finds some mischief still for idle hens to do.

In caring for the youngsters, a little neglect may mean a big loss. Fetter do it right or not at all.

Remember that the early hatcher chicks need an unusual amount of care in order to fully protect them from the cold of early spring.

Have the best stock obtainable, and never start with any other kind. Better get good birds and fewer of them. You can't breed anything but disappointment from poor stock. Is in everything clse, the lest is the cheapest.

Distrust the doctrinaire who says that chicks do not need much heat. They come from a warm place and need considerable warmth until well feathered out. If they have warmth they will grow: if not, they will become stunted and die like flies at the approach of frost.

The whole tendency today on the part of those who have the poultry business most at lieart is towards simplification of methods. The old farmer who feeds nothing but corn and not much of that, letting his hens shift for themselves on the range, may not be the highest type of a poultryman, but he makes 
poultry keeping pay. I le doesn't get many eggs, but what he gets are all profit.

While there are an indefinite number of things a man might do in the poultry busines, yct the things that are absolutely necessary are aftcr all very few. 'To keep one's hens clean, to keep them comfortable, to give them plenty to eat-this is about all there is to it. Perhaps the greatest gain a man ever makes is when he resolves that he will no longer doctor sick hens-unless the sickness is very simple. While he may lose a few more hens in the course of a year than he otherwise would, yet the saving in time, the removal of the strain upon his patience and sympathy, the higher average of health on the part of the hens that remain, more than offset the loss. It was never intender that the poultryman should adkl a drug store to his outfit.

When a man sells eggs he sells futures, and when a man buys eggs he buys possibilities. If a buyer gets a good hatch he gets more than his money's worth, and if the hatch is poor he has no cause for complaint. If only two or three chicks come out, one of these may be a blue-ribbon bird that will be worth ten times what he pairl for the eggs, at the start.

A small flock of layers is better than a big flock of loafers.

If you are a novice and have never exhibited. cnter a few bircls at the fall fairs. You will learn faster in this way than in any other. Iou can apply your newly acquired knowledge a little later to good advantage, and stand a better chance to win when the winter shows open.

The man who orders early gets the choicest of the early stock. Petter buy before the breeders' birds have all been picked orer.

Whatever else you econmize in, do not cconomize in feerl. Feed as if you were a millionaire. Feerl as if grain didn't cost anything. It is possible to get an olel hen too fat, lut a chick on a free range-never.

Pationce and gentleness are two great assets on a poultry plant. It don't pay to get mad with hens.

Not Likely to be Overdone. Is there any tlanger that the ponltry business will be overdone? This is a question that must suggest itsclf to every thoughtful minl. Enormous as the consmmption of eggs and poultry is, may it not be matched and passed by production, so that those who venture into the business will meet with loss? The possibility of this cammot be denied. With ou modern methorls of artificial incubation. by which chicks may be produced at any season of the year and in countless 
numbers, with so many constantly preaching the profits of poultry keeping, there is a real danger that the business may be overdone. There is a limit to everything finite. But on the other hand there are reassuring considerations. This is a big country, and it is growing bigger, all the time. There are 2,000,000 more people in the United States today than there were a year ago, and there will be 2,000,000 more next year than there are now. And all these have to be fed. Game is becoming scarcer each year. Meats are constantly advancing in price. People are being driven into increased consumption of eggs and poultry. When eggs fall in price in the spring their sale enormously increases. This shows that the American people could consume many more eggs than they do now if they thought they could afford them. It is probable that with the advance in scientific methods of production and storage, the price of eggs throughout the year will become more uniform-not soar so high in the fall nor drop so low in the spring. And with an equalization in price, eggs will be used even more than they are now.

Easy to Get Out of. The poultry business has one feature which I have never heard mentioned but which is worthy of consideration; it is easy to get ont of. When a man engages in a new enterprice he naturally hopes and expects to succeed, but all the while the grim alternative of failure must lurk in the background of his consciousness. It is said that a good general before going into battle always determines what he will do in the event of defeat. There are some kinds of business so personal in their nature, so complicated, that a man can get out of them only with considerable loss. But the poultry business is different. Suppose a man has been engaged in the production of eggs and poultry for market, and wishes to close out. All he has to do is to ship his fowls to a comnission merchant in the city, and in a day or two there will come back a check. Suppose a man has been engaged in the production of birds for exhibition purposes. An advertisement in a poultry paper will find him a customer who will take his flock off his hands. There is a good demand for farms, ancl they are steadily advancing in price. Should a man discover that he is unfitted for the poultry business or grow tired of it, he can get out of it with as little loss as any business I know anything about. 


\section{ERRATA.}

On page 7 , the last worl in first line of serenth paragraph should be "Proportions" instearl of preparation.

On page 8 , the figures in third line in third paragraph should read " $\$ \$ 67.45$ " instead of $\$ 86.45$.

On page 9, the figures in sixth line under head, "Marketing the Product," should read " 80 " cents instead of 20 cents. 


\title{
American
}

\section{Poultry Advocate}

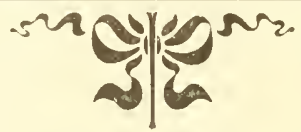

\section{CLARENCE C. DēPUY, Editor and Publisher}

\author{
Issued Monthly. 44 to 116 pages.
}

\section{0,000 \\ Copies \\ Per \\ Month.}

Subscription price, 50 cents per year.

It is devoted to the interests of both fanciers and practical poultrymen, It is authoritative and helpful in all branches of poultry work, from hatching and rearing of chicks, to the maturing of fowls for showroom and market. It is the second oldest poultry publication in the I Jnited States and stands second to none in its value to poultry raisers. It is helpful to the beginner as well as to the expert. The newest and best in poultry literature is found between its covers each month.

The editorial staff is composed of some of the most able writers on poultry topics-men of experience.

From an advertising poin of view it is in a class by itself. The increased advertising patronage we receive yearly from old advertisers, as well as the large amoun of new business, is convincing proof that the ADvocATE is "the paper that pulls." Advertising rates on application.

\section{American Poultry Advocate,}

907 South Salina Street, Syracuse, N. Y. 





